\title{
Water Quality Control at Lake Tahoe: Dissertation on Grasshopper Soup
}

\begin{abstract}
John Ayer*
Lake Tahoe's natural attributes-the lake and the surrounding Sierras-and its artificial attribute-gambling-attract numerous vacationers the year around. This influx has created a threat to the lake's purity and clarity which, in turn, has provoked extensive public response. Professor Ayer analyzes the threats of sewage, sedimentation, solid waste, fertilizer, and shoreline construction and describes the legal and extra-legal responses of the private and governmental institutions involved. He concludes that while not all of the problems have been permanently solved, and while the costs have been high, the lake has been kept fairly clean. As a chronicle of some successful and some not so successful approaches and solutions, his analysis should prove useful in the continuing effort to save our natural resources.
\end{abstract}

Tahoe means . . . grasshopper soup. Mark Twain ${ }^{1}$

By any measure, Tahoe is not an old lake. Geologically, not more than 40 million years ago in the Late Tertiary period of the Cenozoic era, the Sierra Nevada tilted up and a block of the earth's crust dropped, leaving a great trough or graben, which became the lake basin. ${ }^{2}$ Just over a centruy ago, John C. Freinont was the first white man to leave a record of seeing Tahoe, in his journal for February $14,1844 .^{3}$ In terms of water quality, which may be Tahoe's

Acting Professor of Law, University of California, Davis. A.B. 1963, J.D. 1968, University of Louisville; LL.M. 1969, Yale University.

Others who contributed to this paper and deserve acknowledgment are Mr. Robert Heaney, a third-year student at the School of Law of the University of California, Davis, a diligent research assistant, and the Council on Law-Related Studies, which supported the research with a generous stipend. Neither, of course, is responsible for any of the opinions expressed herein.

1. M. TWann, The INNOCEnTs Abroab 146 (Signet Classics ed. 1966). In fairness, Twain was talking about the name, which he disliked, rather than the water itself, which he elsewhere describes as "the rarest picture the whole earth affords." M. Twann, Roughnvg It 134 (Signet Classics ed. 1962).

2. J. Crippen \& B. Pavelka, The Lake Taboe Basin, California-Nevada, U.S. Georogical Survex Open Fite RePort 30 (1969).

3. "Accompanied by Mr. Preuss, I ascended to-day the highest peak to the right 
chief distinction, the lake is still described as oligotrophic, free from excess nourishment, rich in oxygen, or more generally, youthful. ${ }^{4}$

This youthful quality of Talloe's water has given the lake its clarity and thus its distinctive general appeal. ${ }^{5}$ It sets Tahoe apart from numerous other lakes that are fairly described as eutrophic, or in free translation, aged. ${ }^{6}$ Excessive aging promotes ugly algae blooms, coarse fish species and foul odor. ${ }^{7}$

Extensive human activity around Tahoe has disturbed the natural environment in a way that threatens Tahoe's youthfulness. But in a society concerned with its own lost youth, the threat to Tahoe's water quality has provoked a distinctive public response. Particularly in the past ten years, Tahoe has been the focus of an extraordinary public effort to control, through law, its distinctive quahty. To consider this public effort-to discern how it came about, to try to chronicle its development, to measure its successes and its failures and particularly, to examine the operation of the laws involved-may teach us something about efforts to preserve environmental values. It may suggest something about what we can and cannot expect to accomplish in preserving our environment, and how we might best go about it. ${ }^{8}$ Part

.. . from which we had a beautiful view of a mountain lake at our feet, about fifteen miles in length, and so entirely surrounded by mountains that we could not discover an outlet. . . ." Fremont's journal is quoted in G. JAMEs, THE LAKE OF THE SKY: LAKE TAEOE 22 (rev. ed. 1956).

4. See generally K. Stewart \& G. Rohlich, Eutrophication-A Review (1967). Technical data on water quality at Lake Tahoe are extensive. Offieial records are contained in the California Nevada Joint Water Quality Investigations, published annually since 1966. Summaries of a continuing study of eutrophication in general and its implications for Lake Tahoe in particular are: Lake Tahoe Area Council, Eutrophication of Surface Waters-Iake Tahoe, First Progress Report, May 1968; and Second Progress Report, May 1969. Much data has been collected by Dr. Charles Goldman of the University of California at Davis. See, e.g., Goldman \& Carter, An Investigation by Rapid Carbon-14 Bioassay of Factors Affecting the Cultural Eutrophication of Lake Tahoe, California-Nevada, 37 WATER POLLUTION CONTROL Federation J. 1044 (1965); Goldman, Aquatic Primary Production, 8 AM. Zoolo. GIST 31 (1968).

5. To thousands the chief charm of Lake Tahoe is in the exquisite, rare, and astonishing colors of its waters. They are an endless source of delight to all who see them, no matter how insensible they may be, ordinarily, to the effect of color. There is no shade of blue or green that cannot here be found and the absolutely clear and pellucid quahty of the water enhances the beauty and perfection of the tone.

G. JAMES, supra note 3 , at 2.

6. The other famous obgotrophic lakes are Crater Lake in Oregon and Lake Baikal. Foreward to K. STEWART \& G. RoHLICH, supra note 4. There are other oligotrophic lakes, but for the most part they are inaccessible. See Goldman, supra note 4.

7. P. McGauhey, ENgineERINg MaNagement of Water Quality 106-10 (1968). Aging occurs even without human intervention through natural runoff and related phenomena. Human activity can greatly accelerate it, however.

8. Two other general reviews of the legal and political situation, though already 
I of this Article surveys the physical and economic character of the Tahoe basin. It defines the nature of the pollution problem and surveys the principal governmental institutions and the relevant legal definitions involved in the effort to prevent degradation of lake waters. Parts II, III, and IV focus on specific causes of pollution and attempt to evaluate the effectiveness of efforts to end the threats from these sources. Part V discusses the interrelation of Lake Tahoe's role as a water resource and the problem of its quality. Part VI compares the water quality problen to land use planning in the Tahoe basin.

\section{I}

\section{A GENERAL VIEW}

\section{A. Tahoe and Its Problems}

Lake Tahoe is a great trough of blue water draped with a stupendous mountain backdrop. The basin includes 511 square miles of land, of which the lake covers 190 square miles, ${ }^{9}$ straddling the California-Nevada boundary. The water comes from rain and snow, and from the steep surrounding Sierra slopes. The lake has only one drain: the Truckee River which meanders north and east into Nevada, carrying away only a relatively small portion of the lake's immense volume. Around the lakeshore, there is an inner ring of land some two miles wide that is leavily developed with roads, streets, buildings and so forth; in all, soine 70 square miles of flat land. An outer ring of some 240 square miles is virtually empty. ${ }^{10}$ The lake is just 225 miles, or roughly $31 / 2$ hours' driving time, from San Francisco.

Tahoe's initial role in modern civilization was as an obstacle to be surmounted by the pioneers on their way west. ${ }^{11}$ Commercial developinent began in 1861 when a sawmill was built at Glenbrook on the east shore. ${ }^{12}$ In 1873, a pair of entrepreneurs "revolution-

somewhat dated, are still useful. Lake Tahoe Joint Study Comm., Report, Mar. 1967 [hereinafter cited as Joint Study Comm. Report]; Comment, Lake Tahoe: The Future of a National Asset-Lake Use, Water and Pollution, 52 Calif. L. Rev. 563 (1964).

9. A detailed physical description is contained in J. CRIPPEN \& B. PAVelRA, supra note 2. Short summaries are contained in most general studies of Tahoe problems.

10. Id. at 51-52.

11. This discussion of land use patterns follows Mackey, Evolution of Land Use Patterns in the Lake Tahoe Basin with Emphasis on Spatial Patterns Resulting from Early Transportation and Mining Developments, in Grological STUDIES IN THE LAKR Tahoz area, Californta and Nevada, annual field Trip Gumeboor of the Geological Society of SaCramento 67-81 (J. Evans \& R. Matthews eds. 1968).

12. G. JAMES, supra note 3, at 201. 
ized the lumber industry"13 by constructing a narrow-gauge railway from Glenbrook to the Nevada summit, and a V-flume thence to Carson City, opening the way for exploiting Tahoe's vast forest resources as lumber for the Comstock Lode. The heavy lumbering created potential hazards to water quality that have never been fully evaluated or discussed. ${ }^{14}$ But one known lasting consequence of the lumbering era is clear: Tahoe land was assembled in great private holdings that have dictated both private and public development patterns to this day. ${ }^{15}$ The private developinent booin of the 1960 's occurred, in large part, because individual entrepreneurs found large preassembled tracts available for planned umit developinent. ${ }^{16}$ On the other hand, the availability of these large preassembled holdings has also eased the task of public agencies trying to preserve land for public use. ${ }^{17}$

During and after the great lumber booin, Tahoe enjoyed a separate incarnation as an elegant and correspondingly restricted private playground, chiefly for the San Francisco and Sacramento rich-the "Saratoga of the Pacific."18 A consequence of this phase is that it equipped the Tahoe preservation moveinent with interested and occasionally influential supporters across the state.

Recent events not only intensified but also greatly democratized Tahoe's appeal. The nnodern period begins with the coming of bigtime gambling ${ }^{19}$ and the developinent of extensive single-family sub-

13. Id. at 202 .

14. "There is no documentation of the effects of this tree-leveling period upon the watershed, but the disturbance of the soils and the removal of the vegetal cover must have been traumatic to particular sub-basins." Pacific Southwest Region, Federal Water Quality Admin., Lake Tahoe 1970 Status Report on Water Quality Management 78, July 1970.

15. Mackey, supra note 11 , at 80.

16. For example, the Incline Village project is on land purchased from the late George Whittell. Washoe County, Nevada, Deed Book No. 530, at 282 (Reno, Nevada).

17. For example, the Lake Tahoe Nevada State Park, which includes some 12,309 acres, came from Whittell holdings. For a description of the negotiations see Houghton, At Last! A Park for Lake Tahoe, Nevada Highways and Parks, Spring 1965, at 4. At Whittell's death in 1969, he held some 13,400 acres of land in the basin, of which some portion seems destined to go into public ownership. Letter from Kenneth Ashcraft, co-executor of the Whittell estate, to the anthor, July 20,1970, on file with the California Law Review and the Ecology Law Quarterly.

18. The phrase is from an $\mathbf{1 8 6 6}$ advertisement for the Glenbrook House, a resort where "Stylish people" could stay for 21 dollars a week, quoted in G. HinkLE \& B. HINKLE, SIERRA-NEVADA LAKES 284 (1949). For vivid recreations of the old Tahoe ambience, see G. JAMES, supra note 3; E. SCOTT, THE SAGA OF LAKE TAHOE (1957).

19. Gambling has been legal in Nevada since 1931, but the boom at Tahoe dates to the coming of William Harrah, who democratized and rationalized the whole enterprise. See Monroe, The New Gambling King and the Social Scientists, HARPER's, Jan. 
divisions, ${ }^{20}$ roughly simultaneously in the middle 1950 's. The Winter Olympics held nearby at Squaw Valley in 1960 established the basin's role as a winter, as well as a summer, resort. The coinpletion of an all-weather highway some twelve miles north of the lake added the final element necessary to produce the kind of urbanism that has created major problems in maintaining the quality of Tahoe water.

A clear definition of what is degraded water is necessary to determine the success or failure of the effort to maintain Tahoe's water quality. But this task of definition is not simple. Whether a certain body of water is degraded depends, ultimately, on one's notion of its ideal state. A sanitary engineer has said: "Pure distilled water would be a pollutant to the aquatic life of a saline estuary."21

Still, as a beginning, there can be little doubt that fresh water rendered unsafe for drinking and injurious to public health inust generally be regarded as degraded. Hence the principal focus of water control efforts has been historically directed at preserving good drinking water supphies and public health. ${ }^{22}$ In this regard, Tahoe presents particular problems. Control of sewage discharge is only one, and not inevitably the principal, means to this goal. Rather, "purification of water before use for public supply is the first and most important line of defense ....."23 After having obtanied a supply of water by purification, for many communities the most obvious course of conduct has been to dispose of its waste by dumping it back into a body of water. ${ }^{24}$ Disposing of waste into water has at least two advantages. First, water in its natural state does have some capacity to absorb wastes and purify itself. ${ }^{25}$ More to the point, the waste

1962, at 35-41. Gaming revenues for Douglas County, Nevada, which includes all of the south shore casinos, increased from 7,009,700 dollars in fiscal 1955-1956 to 64,751,158 dollars in fiscal 1968-1969. The first figure is reported in ENGINEERna Science, Inc., Comprehensive Study on Protection of Water Resources of Lake Tahoz Basin Throdgh Controlled Waste Disposal 27 (1963) [hereinafter cited as Comprehensive Study]. The second is in Nevada Gaming Comm. Ann. Rep. for the Fiscal Year ended June 30, 1969, at 2. For a jaundiced view of gambling see Brown, Tahoe Notebook, HolidaY, Dec. 1965, at 76-86.

20. Tahoe Paradise, Inc., bought 1,600 acres near the south end of the lake in 1953 and opened its first subdivision unit in 1955. See statement of Jim A.E. Wilson, President, Tahoe Paradise, Inc., in Hearings on Regional Planning in the Lake Tahoe Basin 279-83 Before the Cal. Assembly Comm. on Natural Resources, Planning and Public Works (1964) [hereinafter cited as Hearings on Regional Planning].

21. P. McGaUHEX, supra note 7, at 3.

22. See Hines, Nor Any Drop to Drink, 52 Iowa L. Rev. 186, 202-04 (1966).

23. Cal. Assembly Interim Fact-Finding Comm. on Water Pollution, RePORT 13 (1949) [hereinafter cited as DICKEY REPORT].

24. See generally D. CarR, Death of SweEt Waters (1966); F. Graham, DisASTER BY DERAUUT (1966).

25. P. MCGAUHEY, supra note 7, at 233-43. 
problem if not solved is at least put out of mind. Since water quality control was originally regarded as a local responsibility it was thus possible to dispose of one's waste water problem by making it someone else's problem. ${ }^{26}$ But the Tahoe water quahity situation never was the conventional purification-disposal situation, and for a simple reason. The conventional system depends on moving waters-transport systeins. But Tahoe is not a transport system; it is a sink. ${ }^{27}$ Inflow of water into the lake is slow: water scientists estimate it would take up to 700 years for an empty Tahoe to refill itself naturally. ${ }^{28}$ Tahoe has never suffered significantly from upstream sewage because Cahfornia's rugged mountain geography dictates that Tahoe have few upstream neighbors. Further, it has been well understood that the basim's wastes will not simply float away. ${ }^{29}$ Thus waste disposal into Tahoe has a particularly severe effect on the quality of the lake as a source of drinking water. Similarly, waste disposal has a marked adverse effect on the quality of the lake as a recreation resource.

Taking account of the fact that Tahoe is the most obvious supply of drinking water for the basm, and coupling that with the fact that people have always liked to play in or on its waters, the Tahoe sewage situation has long been attended with a degree of public care and control rarely manifested elsewhere, even in an age when the technical problems of water quality were less clearly understood.

There is another degradation problem at Tahoe that has come into focus only more recently. Tahoe's charm lies not merely in its popularity as a drinking or playing resource, but in its pristine clarity. The threat to clarity is the process of aging. Tahoe ages by taking on nutrients, notably nitrogen, but also phosphorous and perhaps other substances that promote algae growth. ${ }^{30}$ Some of these nutrients get into the lake naturally, and in the long run of geologic time, it is probably correct to say that Tahoe will turn into a great fetid pool or a meadow on its own. But human activities can greatly accelerate this process. For present purposes, the important fact is this: Waste disposal techniques, in addition to preserving water quahty for drinking

26. See Hines, supra note 22, at 202-03.

27. For an eilaboration on the concept of transport systems versus sinks see P. McGaUHeY, supra note 7 , at 15-16.

28. J. CRIPPEN B. PAVELKA, supra note 2, at 71 . Lake Erie can be regarded as a sink, too, but, although it has four times the volume of Lake Tahoe, its flushing time is 2.6 years.

29. At one time, it was suggested that it might be possible to pump waste to the bottom of the lake where it would stay, presumably indefinitely and out of the way. See Lake Tahoe Area Council, Lake Tahoe, May 15, 1966, at 2 [hereinafter cited as Lake Tahoe Newsletter]. The proposition must have been based on the legend that the lake has a hole in the bottom. G. HINKLE \& B. HiNkLE, supra note 18, at 322-25.

30. See K. STEWART \& G. Rohlich, supra note 4, at 29. 
or playing, can contribute significant quantities of damaging nutrients to the lake. ${ }^{31}$

Sewage is not the only threat to the health quality or clarity of the lake. A second threat comes from the extensive land disturbance traceable to cutting and filling for housing and highway construction, or from logging. ${ }^{32}$ The resultant siltation creates a direct and obvious problem for the lake as it changes the lake's pristine blue to a chocolate brown. ${ }^{33}$ It also adds to the potential nutrient supply by destroying natural ground cover which, left to itself, would absorb much of the nutrient supply normally deposited on the land..$^{34}$ Finally, there are related but somewhat specialized hazards to Talıe water quality from solid wastes, fertilizers, and shoreline construction. ${ }^{35}$

\section{B. Governmental Response to the Problem of Water Quality at Tahoe}

\section{The Institutional Setting}

By now it is almost trivial to say that government responsibility for environmental control is fragmented. ${ }^{36}$ The proposition is true as far as it goes, of course. But it obscures the fact that varying agencies occupy roles of vastly differing importance; and the fact that much practical coherency can exist simultaneous with formal fragmentation. At Tal1oe as elsewhere, it is possible to distinguisl agencies that have had major roles in dealing with water quality problems.

In Califormia, historically, the Department of Public Health had primary responsibility for water pollution control..$^{37}$ The Department retaims an active interest in assuring the safety of domestic water supplies and the prevention of contamination. ${ }^{88}$ However, under the Water Pollution Control Act of 1949, known as the Dickey Act, primary responsibility for pollution control passed to a network of nine appointive region-

31. See generally COMPREhENSIVE STUDY, supra note 19. The program of sewage control, first to meet the public lealth threat, and second to meet the more sophisticated hazards confronting the lake's clarity, as discussed in pt. II infra.

32. See generally California Division of Soll Conservation, Sedimentation aNd ERosion IN tHe Upper TrUCRee RIVER aNd Trout CreER Watersheds (1969).

33. For some photos see Goldman, The Bad News from Lake Tahoe, CRY CALIFORNIA, Winter 1967-68, at 18, 22.

34. The problem of sedimentation is the focus of pt. III infra.

35. Efforts to control these hazards to water quality.are. discussed in pt. IV infra.

36. See DickEY REPorT, supra note 23, at 31; Note, California's Water Pollution Problem, 3 Stan. L. Rev. 649, 650-52 (1950).

37. Cl. 60, $\$ \S 5410-45$, [1939] Cal. Stats. 482.

38. See Comment, State Control of Water Pollution: The California Model, 1 U.C. Davis L. REv. 1, 28-30 (1969). 
al boards. ${ }^{39}$ The Dickey Act was substantially revised, although not fundamentally changed, by the Porter-Cologne Act in 1969.40 While the formal constitution of the boards has changed from time to time, they are coinprised of gubernatorial appointees and have various tasks. They are enjoimed, for example, to "obtain coordinated action in water quality control policy."41 To that end, the boards inust "encourage and assist in self-policing waste disposal programs."42 More affirmatively, each board must formulate a regional water quality control plan, ${ }^{43}$ and impose waste discharge requirements for individual waste discharges. ${ }^{44}$ The enabling statute includes a detailed administrative and judicial enforcement scheme. ${ }^{45}$ The regional board responsible for the eastern slope of the Sierra, imcluding the Tahoe basin, is known as the Lahontan Regional Water Quality Control Board.48

Regional boards are supervised by an appointive state board-the State Water Resources Control Board-which is, among other things, the state water pollution control agency for purposes of the Federal Water Pollution Control Act. ${ }^{47}$ Prior to 1969, at least, the role of the state board was substantially secondary to the role of the regional boards. ${ }^{48}$

The scheme in Nevada is somewliat similar, though substantially less complex. The State Department of Health is designated the state

39. Ch. 1549, § 1, [1949] Cal. Stats. 2782, formerly CAL. WATER CODE $\$ \$ 13000-$ 64 , repealed by ch. 482, $\$ 17$, [1969] Cal. Stats. 1051. The regional boards were called water pollution control boards until 1965 when the name was changed to water quahity control boards. Ch. 1657, \$ 7, [1965] Cal. Stats. 3760.

40. CaL. WATER CODE $\$ \S 13000-951$ (West Supp. 1971). See generally Final Report of the Study Panel of the Californa State Water Resources Control BOARD, ReCOMMENDEd CHANGes IN Water Quality CONTROL (1969) [hereinafter cited as 1969 FINAL REPORT]; Robie, Water Pollution: An Affirmative Response by the California Legislature, 1 PACIFIC L.J. 2 (1970).

41. CAI. WATER CODE $\S 13225$ (a) (West Supp. 1971).

42. Id. $\S 13225(\mathrm{~b})$.

43. Id. $\$ \$ 13240-47$. The plan consists of "[a] designation or establishment for the waters within a specified area of (1) beneficial uses to be protected, (2) water quality objectives, and (3) a program of implementation needed for achieving water quality objectives." Id. $\S 13050$ (i). The Tahoe water quality plan has been comprised in the Federal Water Quality Standards.

44. CaL. WaTeR Code $\$ \$ 13260-69$ (West Supp. 1971).

45. Id. $\S \S 13300-61$.

46. Id. $\S 13200$.

47. Id. $\$ 13100-69$. The latest version of the Federal Act is the Water Quality Improvement Act of 1970, Pub. L. No. 91-224, 84 Stat. 91 (to be codified as 33 U.S.C. $\$ \$ 1151-75)$. Primarily it renumbered the previous version, which was codified at 33 U.S.C. $\$ \$ 466-466$ n (Supp. V, 1970).

48. An analysis of the Porter-Cologne Act by a member of the State Water Resourees Control Board concludes that it grants "numerous new powers and duties concerning water quality control which should result in increased State Board leadership and direction to the state's program and much greater State Board influence over the actions and activities of the nine regional boards. The act also greatly increased the State Board's staff." Robie, supra note 40, at 24. 
water pollution control agency for purposes of meeting requirements of the Federal Water Pollution Control Act. ${ }^{49}$ There is a statute making pollution as particularly defined a misdemeanor, ${ }^{50}$ and another empowering the Attorney General to bring injunctive action against stream pollution-thus apparently by implication excluding lakes. ${ }^{51}$ Of much more special relevance, however, is Nevada's "Law Relating to the Protection of Lake Tahoe and its Watershed," passed in 1949 and amended in 1967. ${ }^{52}$ In essence, this law imposes a permit system on construction in the Lake Tahoe basin and vests broad discretionary power to issue or revoke permits in the Health Division of the State Department of Health and Welfare. For example, one provision declares that the division must grant a permit as a precondition of any construction in the basin. ${ }^{53}$ Another prohibits the discharge of sewage within 100 feet of the established high water rim of the lake, but allows the Health Division to make exceptions by permit. ${ }^{54}$

The story of federal involvement is at once simpler and more comphicated-more complicated because an even greater variety of agencies seein to have at least peripheral relevance to the problem; and simpler because the bulk of the activity in recent years has devolved on the Federal Water Quahty Administration. ${ }^{55}$ Another major avenue of federal involvement, though of an entirely separate sense, has been through the U.S. Forest Service, owner of half the land in the basin. ${ }^{56}$ Activities on Forest Service land present various threats to the water quality of the lake. ${ }^{57}$ But the nature of Forest Service operations is such that the water quahity problem is much less substantial as it relates to Forest Service land than as it relates to private land. Also, the U.S. Army Corps of Engineers has control over specified activities that cause pollution in its capacity as issuer of permits for shoreline construction. ${ }^{58}$

At the local level, the governmental and political situation is in many ways surprisingly typical of government im urban areas generally.

49. Nev. Rev. StaT. \$ 445.050 (1967).

50. Id. $\S 445.010$.

51. Id. $\S 445.020$.

52. Id. $\$ 445.080-120$, formerly ch. 306, [1949] Nev. Stat. 616, as amended, ch. 187, [1967] Nev. Stat. 404.

53. Nev. Rev. STAT. $\$ 445.080$ (1967).

54. Id. $\S 445.090$.

55. 33 U.S.C. $\$ 466-1$ (Supp. V, 1970), as amended, Water Quality Improvement Act of 1970, Pub. L. No. 91-224, \& 110 (a), 84 Stat. 113 (to be codified as 33 U.S.C. $\S 1152$ ). The development of the federal statutory scheme is discussed in more detail in pt. II.

56. U.S. Dep't. of Agriculture, Multiple Use Management Plan for National Forest Lands in the Lake Talıe Basin, Forest Service Regions 4 and 5 passim (Prelim. Rev. 1969).

57. People live, work, and camp on forest service land, though not as many as on private land.

58. These activities are discussed in pt. IV. 
There are four counties-Placer and El Dorado in California, Douglas and Washoe in Nevada. There is one developed city-South Lake Tahoe, California, incorporated in 1965. And there is a band of undeveloped land, containing 4.2 of the Lake's 67 miles of shoreline, in the Ormsby Rural Service District of Carson City, Nevada. ${ }^{59}$ There is the characteristic welter of local government service districts-a study four years ago counted 64- of which, for the purposes of discussing water quality, a few deserve special inention. ${ }^{60}$ Specifically, there are eleven special service districts created to provide sewer services: three California Public Utilities Districts; ${ }^{61}$ six coinparable Nevada General Improvement Districts; ${ }^{62}$ and two nore limited Nevada Sewer Improvement Districts. ${ }^{63}$

All of these districts depend, to one degree or another, on local public initiative. A petition of prospective voters begins the creation of a California utility district, ${ }^{64}$ and a special election must be held to carry it out. ${ }^{\circ 5}$ The districts cannot sell bonds without voter approval. ${ }^{68}$ The initiative of property owners or of the county commissioners-who can lardly be expected to act in a situation of this sort except in response to explicit need-creates Nevada general improvement districts. ${ }^{67}$ The issuance of general obligation bonds requires a nuajority vote. ${ }^{68}$ Special assessinent bonds may be initiated without vote, but it may be stopped by protest. ${ }^{60}$ The sewer improvement districts are governed by similar statutes. ${ }^{70}$

\section{Statutory Standards of Water Quality}

In view of the subtleties involved in devising a functional defini-

59. Nev. Rev. Stat. § 277.205 (1969).

60. Joint Study Comm. Report, supra note 8, at 55-56.

61. CAL. PUB. UTIL. CODE $\S \S 15501-18055$ (West 1965), as amended, (West Supp. 1971) (South Tahoe Public Utility District, North Tahoe Public Utility District, and Tahoe City Public Utility District).

62. Nev. Rev. Srar. cl. 318 (1967) (Incline Village, Kingsbury Grade, Kingsbury Grade No. 2, Elk Point, Tahoe-Douglas and Round Hill).

63. Id. cl. 309 (Douglas County Sewer Improvement District No. 1 and Washoe County Sewer Improvement District No. 1).

64. CAL. PUB. UtIL. Code $§ 15702$ (West 1965).

65. Id. $\$ \S 15761-65$.

66. Id. $\$ \S 16815-16$.

67. Nev. Rev. Stat. $§ 318.055$ (1967).

68. Id. $\$ \S 318.290,350.380$.

69. Id. $\$ \S 318.365-366$. Nevada law also allows financing by short-tcrm notes and revenue bonds which do not permit the same degree of voter control, but neither is a realistic source of revenue for major sewer projects. See the discussion in Creegan \& D'Angelo, Sewage Master Plan, Lake Talıo Basin, Douglas County 55-58, Mar. 1968.

70. See generally Nev. Rev. StaT. ch. 309 (1967). Id. § 309.025 provides that "No district may be organized under the provisions of this chapter after May 1, 1967." Cf. id. $\$ 542$. 
tion of pollution, ${ }^{71}$ it is not surprising that there are problems in fashioning a legal definition as well. This is particuarly true in California, where the changes through time constitute a chronicle of increasing sophistication in water quality management.

Before 1949, when water quality control was chiefly a public health responsibility, the controlling mandate gave authorities power to act where waste disposal constituted a health menace or nuisance. This general phrasing proved paralyzingly inexact. ${ }^{72}$

When the Dickey Act created the systein of specialized water pollution control boards in 1949, the drafters parceled out responsibility between the Health Department and the new boards by drawing a distinction between "pollution" and "contamination."73 "Contamination" was defined as a quality impairment that created "an actual hazard to public health," and was left to the Health Department. "Pollution" was defined as "an impairment of the quality of the waters of the state by sewage or industrial waste to a degree which does not create an actual hazard to public health but which does adversely and unreasonably affect such waters for domestic, industrial, agricultural, navigational, recreational or other benficial uses." 74

Time has worked some changes on that defimition. In 1956, the Attorney General discovered that "pollution" and "contamination" may occur simultaneously. ${ }^{75}$ In order to avoid the possiblity that the law might be construed to prevent the water quality control boards from acting in a "contamination" case, the Porter-Colgne Act provides that "'[p]ollution' inay include 'contamination," " thus presumably eliminating any possibility that the water quality control boards might be restricted by a health department failure to act. ${ }^{78}$

Meanwhile, one commentator construed "adversely . . . affect . . . waters for . . . beneficial uses" as used in the Dickey Act to mean actual harm to a beneficial use, ${ }^{77}$ and a lower court accepted this analysis. ${ }^{78}$ Hence, the Porter-Cologne Act declares: "Pollution'

71. See notes 21-35 supra and accompanying text.

72. See ch. 60, $\S 5410-45$ [1939] Cal. Stats. 482; DiCKEY REPoRT, supra note 23 , at $50-55$.

73. See ch. 1549, § 1, [1949] Cal. Stats. 2782.

74. Id.

75. 26 OP. CaL. AtT'Y GEN. 253 (1955).

76. CaL. Water CODE $\S 13050(l)$ (West Supp. 1971). See also 1969 FinaL REPORT, supra note 40, at 29-30. Ch. $482 \$ 36$, [1969] Cal. Stats. 1045, provides that the Porter-Cologne Act is intended to implement the recommendations of this report.

77. Moskovitz, Quality Control and Re-use of Water in California, 45 CALIF. L. REv. 586, 591 (1957).

78. See People v. Libby, McNeil \& Libby, Civil No. 41479 (Butte County Super. Ct., Aug. 16, 1966). 
means an alteration of the quality of the waters of the state by waste to a degree which unreasonably affects: (1) such waters for beneficial uses, or (2) facilities which serve such beneficial uses," thus dropping the requirement of "adverse effect."70 It is questionable whether the old definition ever required such a restrictive reading or whether the new definition necessarily eliminates all the hazards of the old, but the available documentation is clearly calculated to dictate such a result. ${ }^{80}$

Perhaps most intriguing is the evolution of the concept of "beneficial uses." A1 "Statewide Policy for the Control of Water Quality," adopted by the State Water Quality Control Board in $1967^{82}$ includes as "beneficial uses," both "esthetic enjoyment"83 and "waste disposal, dispersion and assimilation." Since the definition of "beneficial uses" in the Dickey Act made no mention of "esthetic enjoyment" unless one can subsume it under "recreational," or the more tantalizing "other beneficial uses," it is questionable whether the board had statutory authority for the inclusion of "esthetic enjoyment" in the 1967 statement of policy. ${ }^{85}$ Under the Porter-Cologne Act of 1969, a new statutory catalog of beneficial uses imcludes esthetic enjoyment, but does not include waste disposal. ${ }^{88}$ The elimination of waste disposal from the catalog of "beneficial uses" was deliberate, and represents a change in legislative attitudes toward water quality. ${ }^{87}$

In Nevada, the closest thing to a general definition of pollution is in the statute which sets forth the general prohibition against water pollution. It hists as unlawful the deposit of "any sawdust, pulp, oils, rubbish, filth or poisonous or deleterious substance or substances which affects the health of persons, fish or livestock, or renders such waters unpalatable or distasteful . . .."88 This language is not greatly different from the state's first major water pollution statute enacted in

79. CAL. WATER CODE $\S 13050(l)$ (West Supp. 1971).

80. 1969 Final REPORT, supra note 40, app. A at 30-31; Robie, supra note 40, at 7.

81. CaL. Water Code $\$ 13050(\mathrm{k})$ (West Supp. 1971).

82. Water Quality Control Board Resolutions 67-7, $67-36$ (on file in Board offices Sacramento, California).

83. Resolution $67-7$, supra note $82, \S 1(f)$.

84. Id. \& 2 .

85. For an interesting account of the legislative history of the Porter-Cologne Act that parallels this analysis see Robie, supra note 40, at 14 n.63. The definition of recreational beneficial uses in CAL. WATER CoDe $\$ 1243$ (West 1956) would hardly seem broad enough to inelude esthetics without more.

86. Cal. Water Code $\S 13050$ (f) (West Supp. 1971).

87. See 1969 Final REPORT, supra note 40, at 25-27; Robie, supra note 40, at 8-12.

88. Nev. Rev. Stat. $\$ 445.010$ (1967). 
1903. ${ }^{89}$ In addition, Nevada's Law Relating to Protection of Lake Tahoe Watershed requires that construction permits "shall be denied when the source of domestic water or the place of disposal of sewage or other wastes would create a health hazard or the quality of Lake Talioe waters would be impaired."

The federal statutes pay surprisingly little attention to possible definitional problems. The provision requiring states to set water quality standards does establish some analytical limits by requiring that standards shall take account of "use and value for public water supplies, propagation of fish and wildlife, recreational purposes, and agricultural, industrial, and other legitimate uses."

\section{II}

\section{SEWAGE DISPOSAL}

\section{A. A Chronicle}

By what amounts to universal agreement, the chief threat to Tahoe's water quality has been sewage disposal. The impulse to contend with the sewage disposal problem, notably over the past ten years, has yielded an extensive and intricate public effort, involving a great variety of public and non-public agencies. By widespread agreement, this effort has achieved a considerable measure of success and is likely to accomplisin more. For the purpose of this analysis, it is useful to briefly chronicle this general effort and to evaluate the contribution of several particularly conspicuous participants.

Agencies responsible for water quality control early singled Tahoe out for special attention. In California, the State Department of Public Health prohibited direct discharge of sewage into the lake in 1915 , at a time when such a rule was "not the general state policy at all."92 Nevada in 1949 prohibited the direct discharge of sewage or other wastes into any water supply in the Tahoe basin. ${ }^{93}$

In the early days, this no-discliarge policy effectively meant a discliarge into septic tanks. Public sewer systems came into bemg in the 1950's under the aegis of the various special service districts created by residents and property owners in the basin. ${ }^{94}$ These sewer sys-

89. Ch. 122, [1903] Nev. Stat. 214.

90. Nev. Rev. STAT. $§ 445.080$ (1967).

91. 33 U.S.C. $\$ 446 a(a)$ (Supp. V, 1970), as amended Water Quality Improvement Act of 1970, Pub. L. No. 91-224, $\S 102,84$ Stat. 91 (to be codified as 33 U.S.C. \& 1153 (a)).

92. See Statement of Dr. Malcolm H. Merrill, then director of the California Department of Public Health, in Hearings on Regional Planning, supra note 20, at 36 .

93. Nev. Rev. Stat. $\$ 445.090$ (1967).

94. For summary of sewer district history see J. Leggett \& F. McLaren, The 
tems were visited by the kinds of problems that descend on sewer systems in growing communities everywhere-deficient capital, population outrunning facilities, occasional notorious overloads and failures. All used some method of ground disposal. The idea of exporting all sewage effluent from the basin, which became a focus of general attention in the 1960's did not receive serious consideration as a policy issue at the time the districts were created. Nevertheless, the Tahoe City Public Utility District, which is located next to the outlet to the Truckee River, located its first disposal site in the Truckee basin and has never discharged directly to the Tahoe watershed.

Studies through these years consistently found the water quality was being preserved. ${ }^{95}$ But once agam, this was an era when water quality control was chiefly a matter for public health authorities. To a large extent, the focus of the early studies is on drinking water standards; they treat more indirect threats to Tahoe's water quality only in a most indirect way.

One early report that did deal at length with the water quality problem in a highly sophisticated way was an engineering survey for the South Tahoe Public Utility District in $1959 .{ }^{96}$ The authors of this survey recognized that the water quality problem at Lake Tahoe was not merely a public health problem. ${ }^{27}$ They contended that even highly treated sewage threatened to put damaging nutrients into the lake so long as it was discharged anywhere in the Tahoe basin. They suggested the ultimate solution: export all effluent from the basin to other watersheds. They went on to say, however, that it seemed practically impossible to find a disposal site outside the basin that would be acceptable to controlling water quality authorities in those waterslieds. Hence they recommended that the District continue with ground disposal inside the Tahoe basin, suggesting that it might be possible to reopen the topic later. ${ }^{88}$

Lake Tahoe Water Quality Problem: History and Prospectus 2-3, June 1968. In California the North Tahoe Public Utility District was formed in 1950, the Tahoe City Public Utility District began providing sewer service in 1951, and the South Tahoe Public Utility District constructed the first unit of its system in 1952. Two small districts were formed iu Nevada in 1953 chiefly to serve the gaming interests that clustered around the borders with California at the north and south ends of the lake. These are Douglas County Sewer Improvement District No. 1 (at the south end) and Washoe County Sewer Improvement District No. 1 (at the north end). Other districts have been created more recently to serve the increasing population.

95. A compilation of early studies is in Division of Water Supply and Pollution Control, U.S. Public Health Service, Compilation of Information Related to Water Quality of Lake Tahoe 45-48 (1961) [hereinafter cited as Coinpilatiou of Information].

96. Brown \& Caldwell, South Tahoe Sewerage Survey, Mar. 1959 (preparcd for the South Tahoe Public Utility District).

97. Id. at 58-81.

98. Id. at 81 . 
The topic was reopened shortly, and in a spectacular way. Perhaps the single inost iniportant figure in this new initiative, was Joseph F. McDonald, a Reno newspaper executive. ${ }^{99}$ McDonald had two significant attributes: a longstanding interest in the lake and good relations with the Max Fleischmaun Foundation, a philanthropic agency that has contributed a great deal of money to various Nevada activities. $^{100}$ McDonald headed the Nevada-California Lake Tahoe Association, created with Fleischmann funds in 1957. And he was instruinental in creating the Lake Tahoe Area Council, a successor group that came into being in 1959 and remains in existence today.

With the urging of state water quality officials and the support of public funds, the Council undertook a comprehensive study of sewage disposal facilities in the Tahoe basin. ${ }^{101}$ The study was carried out by a professional engineering firm under the auspices of a board of eminent scholars. The result, a coinprehensive study on protection of water resources of Lake Tahoe basin through controlled waste disposal, reviewing virtually all the available data on water quality control in the basin, was published in $1963 .{ }^{102}$ This report concluded that the huinan threat to Tahoe "primarily stems from the effects on the lake of nutrients, such as nitrogen and phosphorous, which are contained in waste effluents." 103 It continued:

There is evidence that the clarity of the lake has already been affected by nutrient build-up, and it can be expected that continuation of the present inethods of sewage disposal will result in a progressive decrease in clarity and that within a matter of years eutrophication may occur. . . . If the clarity and beauty of the lake are to be preserved, a new concept of waste disposal for the basin must be developed and implemented as soon as possible. ${ }^{104}$

The report concluded that "[b]y far the best inethod for disposing of waste effluents is to remove these from the watershed ...."105 It recommended either export over the mountains or discharge into the Truckee River, flowing downstream from the lake. The report also countenanced the discharge of highly treated sewage into the lake itself, but warned that "[t]he subject is only beginning to be studied on a sci-

99. Lake Tahoe Area Council, Lake Tahoe Seiche, July 1959.

100. Letter from Julius Bergen, Chairman, Max C. Fleischmann Foundation, to the author, July 23, 1970, on file with the California Law Review and the Ecology Law Quarterly.

101. State water quality control officials seem to have taken the vital initiatives in this effort. See text accompanying notes 148-50 infra.

102. CoMprehensive StUdY, supra note 19.

103. Id. at 128 .

104. Id.

105. Id. 
entific basis," ${ }^{100}$ raising doubts as to whether the production of a nutrient-free effluent was really feasible enough to consider at that point. The study gave its first-preference recommendation to a single disposal system down the Truckee River, while indicating that other systems would be feasible and, in some cases, more economical. ${ }^{107}$

The Council saw to it that the report's recommendations were not hidden under a bushel. The President's Advisory Commission on Water Pollution Control, at the Council's invitation, reviewed the recommendations in a meeting at Tahoe in early fall of $1963 .{ }^{108}$ Following that meeting the governors of California and Nevada met and promulgated a "California-Nevada Governor's Program for Progress," which has remained, despite changes in governors in both states, the basic outline of public policy toward sewage disposal in the basin to this day. It embraced the conclusions of the Council's study, urging sewage export. ${ }^{109}$ As events have transpired, the basic recommendation - sewage export-is in the process of being carried out, but with four disposal systems rather than one. Iromically, the last to reach completion will be the one in the Truckee River area.

Utility districts at the south end of the lake moved fairly quickly to develop export plans. But the difficulties proved chastening. Initially there was the problen of organization. Three districts-one in California and two in Nevada ${ }^{110}$ - at first negotiated for a single unified export scheme. ${ }^{111}$ Ultimately, however, negotiations fell through and separate, parallel export schemes developed on opposite sides of the state line only miles apart with no visible engineering justification for duplication. ${ }^{112}$

Fimancing also prevented difficult problems. Sewer districts in the Tahoe basin, as elsewhere, rely chiefly for financial support on local taxes and on funds from the Federal Water Quality Administration-the so-called "660 money."113 By the middle 1960's it was

106. Id.

107. Id.

108. The meeting is extensively summarized in a letter from the Commission to Anthony J. Celebrezze, Secretary of Health, Education and Welfare, Nov. 18, 1963.

109. The program is reprinted in Water Pollution Hearings on South Lake Tahoe, California, Before the Subcomm. on Rivers and Harbors of the House Comm. on Public Works, 89th Cong., 2d Sess., ser. 36, at 15-18 (1966) [hereinafter cited as Hearings on Water Pollution].

110. The South Tahoe Public Utilities District, Douglas County Sewer Improvement District and a new Round Hill General Improvement District, forned in 1964.

111. Lake Tahoe Newsletter, supra note 29, Aug. 31, 1965, at 7.

112. Cf. id. Sept. 30, 1965.

113. After Federal Water Pollution Control Act of 1956, Pub. L. No. 84-660, 70 Stat. 498, as amended, Water Quality Improvement Act of 1970, Pub. L. No. 91-224, 84 Stat. 91 (to be codified as 33 U.S.C. $\$ \S 1151-75$ ). For a deeper discussion of sewer financing see pt. $I$. 
apparent that the Tahoe region would need extra sources of revenue to meet the financial burden of long distance sewage disposal. In 1965, the California Legislature approved a 1.8 million dollar loan to help finance the South Tahoe project. ${ }^{114}$

The loan, however, was of no use without an export site, and the South Tahoe Public Utility District encountered serious problems attempting to locate one. A proposal to export to the American River was rejected by the Central Valley Water Quahty Control Board. ${ }^{115}$ A second proposal, to export to tiny Alpine County, was thwarted by the Alpime County supervisors. ${ }^{116}$ Thus no site was in evidence in the summer of 1965 when the loan money became available, and when an overload at South Tahoe during the Labor Day weekend created a sewage spill that served to add notoriety to the situation. ${ }^{117}$

The stalemate clearly required leadership or coordination. $R e-$ sponding to the situation, California Governor Edmund G. Brown created an interagency committee on policy and planning to work out a program for the basin. ${ }^{118}$ In time a program did emerge-but from an unexpected source. While the Brown-appointed admimistrative task force was working, a group of legislators and their staff members negotiated a inulti-part agreement which they announced in a joint press conference on January 22, $1966 .{ }^{119}$ Under this agreement, the 1965 loan, then about to expire, was to be renewed. ${ }^{120}$ Alpine County supervisors agreed to accept the sewage export. ${ }^{121}$ And the sewer districts were given the legal tools required to induce all dischargers to connect with sewage systems once available. ${ }^{122}$ With the unanimous backing of the legislators involved, the program inade sinooth progress through the legislature. In addition to the legislative program, the California district in the South Tahoe area received some extraordinary support: an Economic Development Administration loan for 3,253,000 dollars. ${ }^{123}$ With the legislative program and EDA

114. Ch. 1386, § 1, [1965] Cal. Stats. 3307.

115. Central Valley Water Quality Control Board, Minutes of the 77th regular meeting, Apr. 16, 1964, at 5, on file in the Board office, Sacramento, California.

116. 47 Op. CAL. ATT'Y Gen. 40 (1966).

117. Lake Tahoe Newsletter, supra note 29 , Nov. 1, 1965, at 1.

118. Id.

119. The program was announced in a press release and reported im daily newspapers at the time. It is summarized in a report by the AsSEMBLY INTERIM CoMm. on Water, New Horizons in Caltfornia Water Development 42-45 (Comm. Print 1966).

120. Chs. $47 \&$ 157, [1966] Cal. Stats. 1st Ex. Sess. $360 \& 704$.

121. State Water Quality Control Board, Useful Waters for California 60 (Pub. No. 37, 1967).

122. Ch. 48, [1966] Cal. Stats. 1st Ex. Sess. 362.

123. The loan was granted under the Public Works and Economic Developinent Act of 1965. The Act is calculated to create "new employment opportunities" in areas 
loan, plus conventional resources, the hard part of the problem was solved. The export scheme finally went into operation in 1968some three years behind the original deadline, but into operation nonetheless. ${ }^{124}$ The Nevada districts at the south end of the lake also began their separate export scheme at the same time. ${ }^{125}$

The situation at the north end of the lake proved equally complex. With somewhat greater geographic justification, north end districts also chose to develop two export schemes, one in each state, rather than a single system. A district in Nevada on the northeast shore implemented an export scheine in early 1971, after long delays. ${ }^{120}$ The districts around the northwest rim of the lake encountered difficulties raising money which were solved in the same manner as they were at the south end-by state and federal money. ${ }^{127}$ There have been great difficulties locating a suitable and politically acceptable disposal site, which at this writing remain unresolved. ${ }^{28}$ The districts have joined together to occupy a temporary site in the Truckee River basin, but its use is intended to be limited. ${ }^{120}$

Meanwhile in the southeast portion of the basin in Nevada, four new districts have coine into being since 1965 to provide sewer serv-

of "substantial and persistent unemployment and underemployment . . ." 42 U.S.C. $\S 3121$ (Supp. V, 1970). This was the first of several EDA projects in the Tahoe area. The Tahoe projects meet the standards set forth in the Act, but to think of Tahoe's problem as an unemployment problem may present some difficulties to the untutored mind. South Tahoe financing is comprehensively discussed by the project's engineer in Moyer, The South Lake Tahoe Water Reclamation Project, PuBlic Works, Dec. 1968, at 87-94.

124. Moyer, supra note 123, at 88-91.

125. A description of the Nevada south end project is in Creegan \& D'Angelo, supra note 69 , at $18-19$.

126. This is the Incline Village General Improvement District, created in 1962. Incline developed a scheme to export to the Washoe Valley, but it was thwarted by local opposition. Then it developed the notion that it could handle the problem by spraying the treated effluent on golf courses as fertilizer. Ultimately under pressure from Nevada health authorities, Incline did develop an export scheme that came into being in 1971. This account is based on interviews with Ernest Gregory, Chief of the Nevada Division of Environmental Health, Aug. 11, 1970 and Mar. 8, 1971, and with W.W. White, General Manager of the Incline Village General Improvement District, in Incline Village, Nev., Aug. 14, 1970.

127. Primarily, this refers to the North Tahoe Public Utilities District and the Tahoe City Public Utilities District in California. The Washoe Sewer Improvement District No. 1 is currently running its effluent to North Tahoe, but at this writing there is under consideration a scheme to tie Washoe in with Incline. For the financing aspects see pt. II.

128. See Lahontan Regional Water Quality Control Board and Placer County Health Dep't, A Comprehensive Report on the Disposal of Sewage from the North Tahoe Public Utilities District and the Tahoe City Public Utilities District A-1, May 1970.

129. North Tahoe Public Utility District \& Tahoe City Public Utility District, An Invitation to Visit the Cinder Cone, July 15, 1970. 
ice. ${ }^{130}$ None is providing sewage export at this time. As a group they negotiated with the proprietors of the Round Hill-Douglas export facility, a Nevada district in the south end, but these negotiations broke down. At this writing the four are developing an export plan in cooperation with the California South Tahoe district. ${ }^{131}$

Since 1963 the export schemes have been carried forward under a series of more or less authoritative deadlines, none of which has been met. The governor's 1963 program called for soutl shore export by $1965 .{ }^{132}$ It was done by 1968 . A Federal Water Quality Control Conference in 1966 called for export for the entire basin by $1970 .^{133}$ There was some ambiguity in the initial recommendation as to whether this meant completion of export facilities only or export facilities plus all hookups. ${ }^{134}$ The Lahontan Regional Water Quahty Control Board interpreted it to mean the completion of all hookups and wrote that deadline into its water quality control standards, approved by the Department of Interior in 1969. ${ }^{135}$ The California Legislature adopted a statute dictating such a result. ${ }^{136}$ When it became clear that the 1970 deadline was impossible, the Legislature amended this statute to set a deadline of $1972 . .^{137}$ The federal conference recommendation calling for export by 1970 has never been revised, but it now appears that the 1972 deadline also will be missed. Indeed, it now appears the absolute export policy itself will be dropped, allowing some small portions of the basin to go without export facilities pernianently. ${ }^{138}$

130. See generally Creegan \& D'Angelo, supra note 69; letter from Lester $H$. Berkson, attorney for the districts, Stateline, Nevada, to the author, July 9, 1970, on file with the California Law Review and the Ecology Law Quarterly.

131. Tahoe Daily Tribune, June 11, 1970, at 1, col. 7.

132. Hearings on Water Pollution, supra note 109.

133. 1 Federal Water Pollution Control administration, U.S. Dep't. of INTERIOR, CONFERENCE IN the MatTer of Pollution of the INTERState Waters of the Lake Tahoe and Its Tributaries, Proceedings 301 (1966) [hereinafter cited as Conference Proceedings] (item No. 8, "findings and recoinmendations"), which reads in part: "Sewage export from the Basin is to be achieved on a time schcdule which will insure preservation of the water quality of Lake Tahoe and is to be completed by 1970."

134. This is true at least in the minds of Nevada state officials. Interview with Emest Gregory, Director of the Nevada Division of Environmental Health, in Carson City, Nevada, Aug. 11, 1970.

135. 18 C.F.R. \$ 620-10 (1970). See State of California, The Resources Agency, Lahontan Regional Water Quality Control Board, Lake Tahoe Water Quality Contro1 Policy, Addendum Regarding Implementation 4-6, adopted May 1967, revised Oct. 1967.

136. Ch. 556, [1968] Cal. Stats. 1222.

137. CaL. Water CODE $\$ 13951$ (West Supp. 1971).

138. The California Legislature's embargo on in-basin sewage disposal does recognize such a possibility. Id.; see note 127 supra. 


\section{B. Critique of the Sewage Disposal Effort}

\section{Local Effort}

The brunt of the sewage-export program has been borne by the special districts in the two states-public utilities districts in Cahifornia and general or sewer improvement facilities in Nevada. These districts cannot exist or function effectively without local support. In the last analysis, sewage-disposal programs depend on the willingness of local people-people who hive, or work, or at least own real estate and hence pay property taxes in the basin-to undertake public programs and to pay their costs.

Sewage export from the Tahoe basin is being carried out only because of local support. But it has been far from unanimous or enthusisastic. The export scheine is extremely costly-costly enough to provoke hearty resistance froin the homeowners confronted with the bill. ${ }^{139}$ A county official remarked just recently on the position of a homeowner confronted with a bill of several thousand dollars for a sewer: "[T] hey must feel that they are unfairly burdened to carry the entire load of saving the Lake so that all others, who are not property owners and taxpayers in the area, can enjoy its unspoiled splendor."140 More will be said about the logic of this attitude later. ${ }^{141}$ In the meantime, it is surely an intelligible, if not completely defensible, position. One measure of this public attitude may be the public response to revenue-raising proposals for export facihties. South Tahoe voters rejected three successive revenue-raising proposals before accepting one in 1966. ${ }^{142}$ Kingsbury General Improvennent District voters turned down a noney proposal last year. ${ }^{143}$ The Incline Village General Improvement District has not used voted bonds, but the general manager said this year, "I would believe that general obligation bonds might be defeated." Sit4 Similarly, the attorney for the Round Hill General Improvement District reports, "[i]t is doubtful that

139. Current estimates put the total cost of sewer services for the typical homeowner in the basin as high as 8,000 dollars. Interview with William Layton, treasurermanager of the Tahoe City Public Utilities District, in Tahoe City, Calif., Aug. 14, 1970.

140. James E. Williams, Placer County Administrator, quoted in Placer County Planning Dep't, Placer County's Symposium on Lake Tahoe Euvironment Workshop 41, Apr. 3, 1970.

141. See pt. IV.

142. Letter froin Rnssell L. Culp, General Manager of the South Tahoe District, to the author, July 9, 1970, on file with the California Law Review and the Ecology Law Quarterly.

143. Letter froin Lester Berkson, supra note 130.

144. Letter froin W.W. White, General Manager, to the author, July 10, 1970, on file with the California Law Review and the Ecology Law Quarterly. 
any bonds could be successfully passed or sold at the present point in time . ..."145 Four other districts in the basin have had better luck with votes, but the remaining three have not yet embarked on major financing of sewer improvements. ${ }^{146}$ Thus the record of local support is at best ambiguous. And this record itself has been achieved only in a context of extensive and varied outside pressure. ${ }^{147}$

One other aspect of the local effort deserves attention. The Lake Tahoe Area Council's report of 1963 recommended that the export scheme be carried out through a single pipeline, though conceding that more than one might be cheaper. ${ }^{148}$ In the scheme that is actually developing, there will be four. This duplication is particularly strange at the south end of the lake, where two export pipelines rise over the mountains from the same valley, just miles apart. It is impossible to say exactly why the single-line scheme did not come to pass at this point. It is a question of motives, which are always, ultimately undiseernible. Moreover it involves conflicts and compromises among individuals many of whoin are still alive and active; hence frank appraisals are not always available. ${ }^{149}$ However, some ideas emerge from conversations with people who have participated in the decisionmaking process at Tahoe. Ultimately these reasons revolve around the fact that there was no single authority who could impose an efficient solution. For example, at the south shore, relations between the districts under a prior sewage-treatment agreement had not been good, and they set out to negotiate the new one in an atmosphere of suspicion that was bound to complicate their relations. Also, Nevada gambling interests evidently felt restive about a situation that made them vulnerable to California political fortunes. More negatively, there were problems of coordination between the two states; for example, it proved difficult for districts in eacli state to get to the top of others' schedule

145. Letter from Noel E. Manoukian to the author, July 20,1970, on file with the California Law Review and the Ecology Law Quarterly.

146. Districts that have successfully put bond issues to a vote include North Tahoe [Letter from Thomas E. Llewellyn, General Manager, to the author, Aug. 26, 1970]; Tahoe City [Letter from William B. Layton, Jr., Treasurer-Manager, to the author, July 21, 1970]; Washoe Sewer Improvement District No. 1 [Letter from Newell F. Hancock, Secretary, to the author, July 28, 1970] and Douglas County [Interview with Milton Manoukian, attorney for the District, in Zephyr Cove, Nevada, Aug. 15, 1970]. Copies of these letters are on file with the California Law Review and the Ecology Law Quarterly. Those that have not yet put bond issues to a vote include Kingsburg General Improvement District No. 2, Tahoe-Douglas, and Elk Point. Letter from Lester H. Berkson, supra note 130; interview with Berkson, in Stateline, Nevada, Aug. 10, 1970.

147. See notes 151-69 infra and accompanying text.

148. COMPREHENSIVE STUDY, supra note 19, at 118-20.

149. For all the data that exist about Tahoe, there is surprisingly hittle information in print on this point. But see Moyer, supra note 123, at 87-94. 
of spending priorities at the same time.

Finally, there seems to be some truth in the proposition that the different districts and neighborhoods each has what a federal official recently described as "a vested interests in one's own sewage."160 To the local attorneys and consulting engineers, a sewer district means professional fees. To the staff, some of whoin are in a position to influence decisions, it means employment. To the directors, it may be a strong hand in the contention of local pride and animosity.

\section{The State Presence}

Agencies with a statewide constituency have supphed the initiative at almost every significant point in the effort to deal with Tahoe's sewage-disposal probleins. ${ }^{151}$ To a large extent this has meant, in Nevada, the Health Division of the Department of Health, Welfare and Rehabilitation, ${ }^{152}$ and in California, since 1950, the Lahontan Regional Water Quality Control Board. ${ }^{153}$ Both agencies have steadfastly maintained a no-discharge policy ${ }^{154}$ and were, respectively, the authors of the water quality standards adopted as state pohicy under the Federal Water Quality Control Act of $1965 .^{155}$ Staff members of both agencies have been instrumental in providing advice and encouragement for the creation of the sewer districts in the two states. ${ }^{150}$ In California, where the documentary evidence is more plentiful, it is clear that the Lahontan Board staff has focused large portions of its time on various activities calculated to encourage sewage export-advising, coordinating, disseminating information, and so forth. The

150. Remark by Paul DeFalco during panel discussion, Tahoe Regional Planning Agency Environmental Planning Conference for Lake Tahoe, in Crystal Bay, Nev., May 3, 1970.

151. See generally Hines, supra note 22, at 186; Comment, supra note 38.

152. See notes 49-54 supra and accompanying text.

153. See notes $39-48$ supra and accompanying text. A regional board has a statewide constituency becanse it is appointed by the Governor and supervised by a state board. See CAL. Water Code $\$ \$ 175$ (West 1971), 13201 (West Supp. 1971).

154. For Nevada see Nev. Rev. Stat. $\$ \$ 445.080,445.100$ (1967); Nevada Division of Health, Laws Relating to the Protection of Lake Tahoe Watershed and Regulations Governing the Lake Tahoe Watershed 5 (1967). For California see Lahontan Water Quality Control Board Resolntion 52-3 (adopted Sept. 25, 1952) and Resolntion 58-1 (adopted Mar. 12, 1958) on file in Lahontan Board office, Bishop, California.

155. 18 C.F.R. \& 620.10 (1970).

156. The staff work of the Lahontan Board is rccorded in written summaries of staff activity furnished and filed along with Board agendas. The role of Nevada state officials is suggested by their repeated presence at meetings and conferences on Tahoe pollution. For a suggestion of the seminal role of both states in promoting sewage export see a letter from Cecil Edmonds, Lahontan Regional Board member, to R.M. Smith, then Planning Execntive Director of the Lake Tahoe Area Conncil, Jan. 21, 1960 , on file in Board office, Bishop, California. 
Lahontan Board has set explicit "waste discharge requirements" for the three sewer districts operating in California. ${ }^{157}$ In addition, the Nevada Health Division and the California State Water Quality Control Board have served as conduits for federal money, and their support has helped to assure that Tahoe got its share of the relatively sparse Public Law 660 funds.

What is striking about this effort is how little of it has involved anything that resembles a formal enforcement process. It is true that the chief of the Nevada Bureau of Environmental Health has from time to time exercised his authority to refuse building permits to developinents that are not adequately sewered. ${ }^{158}$ But it would be difficult to show that this occasional conduct has significantly restricted land development. Meanwhile, in California in 20 years the Lahontan Board has issued only two cease-and-desist orders. ${ }^{159}$ It has gone to court only once; in that one outing it lost. ${ }^{160}$

A review of one case in which the board did issue a cease and desist order may suggest a more typical means of operation. The incident involved the North Taloe Public Utilities District. ${ }^{101}$ The District began having trouble with sewage spills in the spring of 1966, at which time the Board's Talıe staff engineer, Fred McLaren, sent a letter warning the District that it might be in violation of the prevailing waste discharge requirement. Other isolated spills resulted in McLaren's presence at a District board meeting, at which it developed that the District foresaw the possibility of extensive overloading in the spring of 1967. The day after that revelation, the county health officer declared that he would approve no more building permits until the

157. Currently effective waste discharge requirements are: for the South Tahoe Public Utilities District, Lahontan Board Resolution 67-21 (July 27, 1967); North Tahoe and Tahoe City Public Utilities Districts, Resolution 68-5 (Feb. 21, 1968) (revised Apr. 25, 1968) on file in Board office, Bishop, California.

158. Interview with Emest Gregory, director of the Nevada Bureau of Environmental Health, in which he mentioned his use of NEV. REV. STAT. $\$ 445.080$ (1967), in Carson City, Nevada, Aug. 11, 1970. The Environmental Health Bureau is an arm of the Health Department.

159. An order against the South Tahoe Public Utilities District was issued in Oct. 8, 1965, and lifted in 1966. Lake Tahoe Newsletter, supra note 29, Nov. 1, 1965, at 1. See also People v. South Tahoe Pub. Util. Dist., Civil No. 14531 (El Dorado County Super. Ct., Dec. 27, 1965). An order against the North Tahoe Public Utility District was issued March 22, 1967, and lifted April 25, 1968. Lahontan Board, Minutes of the 19th special meeting, Mar. 22, 1967; Minutes of the 72d regular meeting, Apr. 25, 1968.

160. People v. South Tahoe Pub. Util. Dist., Civil No. 14351 (El Dorado County Super. Ct., Dec. 27, 1965). The Board sought an injunction in support of a cease and desist order, but the application was denied after a hearing.

161. The following account is taken from Lahontan Board ininutes for meetings from Mar. 22, 1967, to Apr. 25, 1968, inclusive, on file in Board office, Bishop, California. 
defect was corrected. The following day the executive director of the Lahontan Board wrote a letter to the county health officer supporting this action. A month later, the Lahontan Board sent a letter saying, as the Board's minutes put it, "the Regional Board staff would recommend that the Board issue a cease and desist order against the District."102

The Lahontan Board entered the matter in a formal way March 22, 1967, with a special Board meeting at which McLaren recounted the history of the problem. An engineer for the District conceded that the account was accurate, and said the District was trying to respond by developing a prograin of sewer repairs. But he raised doubts as to whether the District had money enough to finish the project that summer. McLaren concluded by saying he felt the District should make reports to the Board at each of its meetings, and weekly reports to the staff; to which the District agreed. Despite this, the Board voted to issue its cease and desist order. At the Board meeting the following unonth, the chairman called for a progress report, saying that 'if the Board finds the District is not making every attempt to comply with the cease and desist order, the Board would refer the matter to the District Attorney for injunctive proceedings."163 Again the engineer reported that the district had prosecuted a repair prograin and it had brought special equipment to use in emergencies. McLaren was making regular inspections and attending meetings of the District's own board. The Board voted "to accept the report" and also urged the officials of the District "to continue their vigilance and dedicate all of their efforts to the early cessation of the discharge . . .."104 The District reported again in July and once again the Board resolved to hold the cease and desist order in abeyance. ${ }^{165}$ In October, the District reported it was doing what it could to correct the situation, and asked that the cease and desist order be removed. ${ }^{160}$ McLaren opposed lifting the order, saying it would not be clear how well things were going until the spring. The District made yet another progress report in January ${ }^{167}$ and another in April. ${ }^{168}$ At that time, McLaren recommended that the cease and desist order be dropped. The Board did so, and instructed its staff to issue a news release on its decision. ${ }^{100}$

162. Mimutes of the 19th special meeting, Mar. 22, 1967, at 5. The phrasing is not completely free from irony, in that the Board is nominally the supervisor of the staff, rather than vice versa.

163. Minutes of the 68th special meeting, Apr. 27, 1967, at 7.

164. Id. at 10.

165. Minutes of the 69th regular meeting, July 27, 1967.

166. Minutes of the 70th regular meeting, Oct. 26, 1967.

167. Minutes of the 71st regular meeting, Jan. 25, 1968.

168. Minutes of the 72d regular meeting, Apr. 25, 1968.

169. Resolution 68-10, id. 
This account is at least fairly suggestive of the means the Board has at its disposal short of formal enforcement. The system exhibits a flexibility which is surely desirable in many' such cases. The obvious defect is that the standard of good faith is perilously elastic, and such a process presents beguiling opportunities for foot-dragging on both sides, not to mention outright collusion-though this is not to suggest that there has, in fact, been abuse.

It seems useful to speculate on what prompts the Board's characteristic reluctance to press on for court enforcement. At a most elennentary level, of course, it may be simply that the agency believes it can do a better job with the case and does not care to subject its policies to the hazards of court review. ${ }^{170}$

At a nore specialized level, it is clear that under the Dickey Act, there were some apparent gaps in the statutory enforcement structure. Chief of these was the question whether the Regional Board, prior to 1970 , did in fact have power to regulate for mere "esthetic enjoyment." "171 If it did not, many measures directed at quality control at Lake Tahoe were of questionable validity. The Dickey Act was also criticized as having been too cumbersome in its application, and too restrictive in its enforcement provisions. The committee report proposing the Porter-Cologne Act described the old enforcennent scheme as "totally inadequate."172

170. "[T] he courts are not experts on pollution, and the outcome of a court case is always somewhat unpredictable. Once a case goes to the courts, the final decision is no longer in the hands of the pollution control agency." J. DAVIES, THE PoLimcs of Pollution 185 (1970).

171. See text accompanying notes 81-87 supra.

172. See 1969 FINAL REPORT, supra note 40, at 19-22. In particular:

For example, the [Dickey] act now provides that any person proposing to discharge wastes into waters of the state shall first file a report of such proposed discharge with the regional board. The regional board thereafter establishes requirements as to the nature of his discharge or the condition to be maintained in the receiving waters. If a report is not filed, the regional board may go to court to secure an injunction prohibiting the discharge of waste until the report has been filed. However, once the report has been filed, the board has no jurisdiction to prohibit a discharge that occurs after the filing of the report and before the waste discharge requirements have been established by the board. Thus, if the board has reason to believe that a proposed waste discharge might be harmful to the waters of the state, it may prohibit that discharge until a report thereon is filed. But, once the report of discharge is filed, even though the report indicates that the proposed discharge would indeed be harmful to waters of the state, the board is not authorized to take any corrective action until requirements have been established, which usually takes several months. Another example relates to the restricted applicability of the 'cease and desist' procedure, which is the initial step in the enforceinent procedures. Section 13060 now authorizes issuance of a cease and desist order only where two conditions exist: (1) a waste discharger is violating requirements and (2) 'such discharge is threatening to cause or is causing a pollution or a nuisance.' No allowance is made under the second condition for the effects of discharges by others, although water quality reflects many discharges 
A more fundamental reason for the very modest amount of enforcement activity under the Dickey Act may be that pollution control efforts-particularly with regard to community sewage control programs-are always ultimately unenforceable. ${ }^{173}$ It may well be that a statute says all sewage shall be out of the basin by $1972,{ }^{174}$ and that a statute gives the board power to go to court and get equitable orders $^{175}$ - even, as of 1970 , to impose large "civil monetary remedies."176 But the sewage control effort depends, ultimately, on local efforts-local creation of special service districts, local support for funding schemes. The same people who vote for those legislators who vote for antipollution laws simply cannot be counted on in every instance to pay the bill for the facilities. It is in this sense, perhaps, that pollution is, in John Kenneth Galbraith's phrase, "the nation's most broadly based and democratic effort." 177

\section{The Federal Presence}

Developing more or less simultaneously with the water quality problem at Lake Tahoe has been the federal interest in water quality control. ${ }^{178}$ This interest has manifested itself in several noteworthy episodes at Tahoe. The U.S. Public Health Service prepared various reports on Lake Tahoe pollution prior to 1961. The President's Water Pollution Control Advisory Board met at Tahoe in the summer of 1963. The Water Pollution Control Administration convened an interstate conference there in 1966. In response to the 1965 Act, the states prounulgated water quahity standards. And finally, the federal government has contributed money for the capital requirements of sewage treatment facilities in the basin.

\section{a. The Public Health Service}

Pollution control activities of the federal government were under

of waste. It is the discharge of the person against whom the cease and desist order is directed which-apparently alone-must be causing or threatening to cause the pollution or nuisance! The statutory restriction has made enforcement practically impossible.

Id. at 19.

173. "All available experience indicates that laws against pollution, like all other laws, must rest primarily on voluntary action if their purpose is to be achieved." $J$. Davies, supra note 170 , at 185 ; $c f$. lecture by $M$. Holden at the Water Resources Center, Comell University, May 16, 1966.

174. CaL. Water CoDe $\$ 13951$ (West Supp. 1971).

175. Id. \$ 13331 .

176. Id. \& 13350 . 54.

177. Galbraith, The Polipollutionists, THe ATLANTIC MONTHLy, Jan. 1967, at 52,

178. 33 U.S.C. \$\$ 466-66n (Supp. V, 1970), as amended, Act of Apr. 3, 1970, Pub. L. No. 91-224, 84 Stat. 91 (to be codified as 33 U.S.C. \$\$ 1151-75). See generally Comment, Federal Programs for Water Pollution Control, 1 U.C. DAvis L. REV. 71 (1969); Hines, supra note 22, at 799. 
the control of the Surgeon General prior to $1961 . .^{179}$ His efforts at Tahoe were largely devoted to reporting information most of which was available elsewhere. A federally prepared Compilation of Information Related to Water Quality of Lake Tahoe, issued in September, 1961, provided an extensive review of earlier studies, state, federal and private, running back to $1946 .{ }^{180}$ It called attention to the sophisticated water quality problems, beyond the drinking water problem that were to beset Tahoe for the rest of the decade. Also, it recommended planning to "show what sacrifice, whether in water quality or economic development, is necessary to insure adherence to those objectives that represent the desired social benefit."181 The report was only what its name signified-a compilation of data collected by others, chiefly state agencies. Except insofar as it collected data from disparate sources, it contributed little to the solution of the Tahoe problem.

\section{b. The 1963 meeting}

The President's Water Pollution Control Advisory Board was established under the 1956 Act. $^{182}$ At the mvitation of the Lake Tahoe Area Council, the Board met at Tahoe on September 27, 1963. ${ }^{183}$ As a result of that meeting, the Advisory Board later adopted a resolution urging that steps be taken to prevent further Tahoe pollution. ${ }^{184}$ Also, on the heels of that meeting the two governors met and authorized a program "to prevent degradation of the quality of the water of Lake Tahoe and its tributaries . . ."185 Deane Seeger, the executive director of the Lake Tahoe Area Council, said later that "after committee spokesmen suggested that it was necessary for the federal government to intervene to protect Lake Tahoe (an interstate body of water), the two state governments were quick to act." ${ }^{\text {"188 }}$ With all respect to a conscientious public person, the re-

179. Authority was vested in the Surgeon General under the original Act of June 30,1948 , ch. $758, \S 1,62$ Stat. 1155 . It was transferred to the Secretary of Health, Education and Welfare by the Federal Water Pollution Control Act of July 9, 1956, ch. 518, § 1,70 Stat. 498.

180. Compilation of Information, supra note 95, and earlier studies in App. A, at $45-48$.

181. Id. at 3.

182. Act of July 9, 1956 , ch. 518, \& 7, 70 Stat. 503, as amended, 33 U.S.C. $\S 466 \mathrm{f}$ (Supp. V, 1970), as amended, Water Quahty Improvement Act of 1970. Pub. L. No. 91-224, 84 Stat. 91 (to be codified as 33 U.S.C. \& 1159).

183. S.F. Chronicle, Sept. 27, 1963, at 2, col. 5; id., Sept. 28, 1963, at 1, col. 8.

184. Id., Nov. 11, 1963, at 5, col. 4. See text accompanying note 108 supra.

185. California-Nevada Governors' Program for Progress, Nov. 1963, reprinted in Hearings on Water Pollution, supra note 109, at 17.

186. Lake Tahoe Area Council Topic Report No. 64-1, Sewage Disposal and Water Pollution Control in the Lake Tahoe Basin 4, 1964. 
mark has a disingenous ring. Surely, given the limited powers of the federal government in the field at the time, the hazard of federal intervention could not have been a inajor concern. It is easier to conceive of the federal threat as an excuse, than as a justification, for action.

\section{c. The 1966 conference}

Section 10 of the 1956 Act einpowers the federal authority, in this case, the Secretary of the Interior, to call a conference when, on the basis of reports, surveys or studies, he has reason to believe that pollution of interstate waters subject to abatement under the Federal Act is occurring. ${ }^{187}$ Such a conference was convened at Tahoe on July 18-20, 1966. ${ }^{188}$ The conference was an important event in the breaucratic life of the Federal Water Pollution Control Administration. Commissioner Quigley, who himself attended, noted that the department had been lately transferred from Health, Education and Welfare to Interior. ${ }^{189}$ The Tahoe conference was the third of three conducted by FWPCA as its imitial public program in its new hoine. The others were Lake Erie and the Chattachoochee River. Commissioner Quigley remarked that "it would be almost impossible to pick three more divergent areas," ${ }^{190}$ and the clioices surely did serve to illustrate the range of the nation's pollution problem.

A total of 33 persons, including the conferees and the federal officials, made statements at the conference. At the end of the conference, the formal participants concurred in a list of "findings and recommendatons," generally calculated, as in the past, to keep the lake pure and clear. ${ }^{191}$ Specifically, the conference called for sewage export by $1970 . .^{192}$

The role of the conference is not completely self-evident, but it seeins clear that it was designed more to mobilize support for water pollution control than as a real step toward solution of specific problems. Murray Stein, the federal conferee, described the purpose of the conference as:

187. 33 U.S.C. $\$ 466 \mathrm{~g}(\mathrm{~d})(1)$ (Supp. V, 1970), as amended, Water Quality Improvement Act of 1970, Pub. L. No. 91-224, $\S 112,84$ Stat. 114 (to be codified as 33 U.S.C. $\S 1160(d)(1)$. Administration of the Act was transferred first to the Secretary of the Interior by Reorganization Plan No. 2 of 1966, 31 Fed. Reg. 6857 (1966), and then to the new Environmental Protection Agency, 35 Fed. Reg. 15623 (1970).

188. Testimony and submitted statements are contained in 1 Confrrence ProCEEDINGS, supra note 123.

189. Id. at 12 (James M. Quigley, Commissioner of the Federal Water Pollution Control Administration).

190. Id. at 13 .

191. Id. at 298-303.

192. Id. at 301 . 
to review the existing pollution situation, to appraise what has been done, to correct the situation so far, to lay a basis for future action, and give the states and localities an opportunity to take whatever remedial action is possible and practicable under state and local law. ${ }^{193}$

He pointed out that the conference technique is not a new one. Previously, it had been used informally by many state agencies in their attempt to control water pollution. ${ }^{194}$ In the Tahoe situation, however, a conference was not necessary to encourage cooperation and mutual concessions, as the states had already generally agreed on the solutions. ${ }^{195}$ The federal report on pollution that was used to open the conference was drawn almost exclusively from the Lake Tahoe Area Council 1963 report. ${ }^{196}$ The conference conclusions, to a large extent, only served to ratify what the states had already resolved to do. ${ }^{197}$

This is not to say that the 1966 conference served solely as a publicity episode. Many of the conference goals are not being met. ${ }^{198}$ The recommendations of the conference might at least serve as a convemient benchniark for some future effort to measure the success of pollution control since 1966.

\section{d. Water quality standards}

A central provision of the 1966 Act, and one of the most hotly disputed, ${ }^{199}$ is the requirement that states set water quality stand-

193. Id. at 6 (opening statement of Murray M. Stein, Assistant Commissioner for Enforcement, Federal Water Pollution Control Administration).

194. Id.

195. See id. at 17-32 (statements of the two governors). The testimony of Nevada Governor Grant Sawyer suggests that he felt the federal agency was exaggerating the situation [id. at 25-26], but his remarks seem consistent with the findings and recommendations.

196. See A. West \& K. Mackenthun, Report on Pollution in the Lake Tahoe Basin, California-Nevada, U.S. Department of Interior Federal Water Pollution Control Administration, July, 1966. The report says the Engimeering Sciences report "has been used as the source of the basic and projected data referred to in this report." Id. at 7.

197. See pt. II, $B, 2$ supra.

198. See text accompanying notes 132-38 supra for a discussion of the deadlines that have not been met.

199. Act of Oct. 2, 1965, Pub. L. No. 89-234, § 5(a), 79 Stat. 903, codified as 33 U.S.C. \& $466 \mathrm{~g}(\mathrm{c})$ (Supp. V, 1970), as amended, Water Quatity Improvement Act of 1970 , Pub. L. No. $91-224, \S 112,84$ Stat. 114 (to be codified as 33 U.S.C. $\$ 1160$ (c) ). The section calls for standards "such as to protect the public lealth or welfare, enhance the quahity of water and serve the purposes of this chapter." Officials promulgating the standards "shall take into consideration their use and value for public water supplies, propagation of fish and wildlife, recreational purposes, and agricultural, industrial, and other legitimate uses." They shall also consider "use and value for navigation." Id. 
ards. 200

In California the response to the call for standards was prompt and exphicit. The 1965 Act was enacted on October 2, 1965. The Governor of California, Edmund G. Brown, in a letter dated November 24, 1965, urged the Lahontan Board to act to set standards. ${ }^{201}$ The Board declared its intention to set standards in a resolution December 6, and established a target date of June 30,1966, a full year prior to the deadline set by the federal act. ${ }^{202}$ The Lahontan Board convened a task force to establish standards, and adopted them on June. 23, 1966. ${ }^{203}$ The Nevada State Board of Health adopted standards as an amendment to its State Water Pollution Control Regulations on July 1, 1967.204 The federal government accepted Nevada's standards on November 26, 1968, and California on May 7, 1969. ${ }^{205}$

The standards remain in force. The 1965 Act provides that "[t]he discharge of matter . . . which reduces the quality of such waters below the water quahity standards established [under the act] is subject to abatement."206

No standards have ever been put to a court test, either at Tahoe or elsewhere. ${ }^{207}$ If ever they should be, one may well wonder whether and to what extent they will be enforced.

In the first place, it is a basic fact of the Tahoe situation that the disposal problem involves private waste systems, not industrial waste. Private waste disposal problems are, in an important sense, more intractable than industrial waste problems because there are so many different individuals to deal with. While the export system has not been developed as quickly as once was hoped, it is developing. It is difficult to conceive of what more an abatement proceeding could contribute to induce progress at this point.

Second, it is questionable whether the standards have any inde-

200. See generally Hines, supra note 22 , at $799,825-30$.

201. See Lahontan Regional Water Quality Control Board Resolution 66-11, reprinted in State of California, The Resources Agency, Lahontan Regional Water Quality Control Board, Lake Tahoe Water Quality Control Policy v, June 1966.

202. Laliontan Regional Water Quality Control Board Resolution 66-16 reprinted in State of California, The Resources Agency, Lalıontan Regional Water Quality Control Board, Lake Tahoe Water Quality Control Policy iv, June 1966.

203. Id. at 13-21.

204. See Nevada Bureau of Environmental Health, Water Pollution Control Regulations (1967).

205. 33 Fed. Reg. 18012 (1968) (Nevada); 34 Fed. Reg. 7800 (1969) (California). 206. 33 U.S.C. $\$ 466 \mathrm{~g}(\mathrm{c})(5)$ (Supp. V, 1970) as amended, Water Quality Improvement Act of 1970, Pub. L. No. 91-224, $\$ 112$, 84 Stat. 114 (to be codified as 33 U.S.C. $\$ 1160$ (c) (5)).

207. Of the 45 enforcement conferences initiated, only four have gone to the public-liearing stage-the last, 10 years ago. J. DAvies, supra note 170 , at 187. 
pendent force in abatement proceedings. The statute makes explicit provision for "a complete review of the standards" in the enforcement proceeding, which is as inucl as saying the polluter can start froin scratch. $^{208}$ Other possible avenues of attack on standards have been suggested elsewhere. ${ }^{209}$ Thus, the efficacy of standards as a device for enforcing water quality at Tahoe remains at least open to question.

\section{Money}

Surely among the most important problems in the sewer-building prograin at Tahoe has been the need for money. Indeed it may liave been the inost important problem. The man who has been the inost active single professional planner in the Tahoe basin said in 1967: "There is really no problein at Tahoe, which could not be solved, and rather quickly, too, with adequate (copious) amounts of money. Engineering problems, such as sewage, roads etc., require only time and money, both it seems in increasing amount."210

This is not surprising in itself, since money has proven to be the relevant parameter in pollution control everywhere. ${ }^{211}$ It has been aggravated at Tahoe lowever. The peculiar geography of the lake basin and the peculiar need for high standards in the lake water together have dictated an extraordinarily costly prograin of sewage disposal. In addition, the need for sewer-building-particularly expensive sewerbuilding - has thrust Tahoe area residents in conflict with others who come to enjoy the lake. The residents argue that if outsiders are really interested in protecting the basim, then money is nore important than advice. The point was made less bluntly, but forcefully, by an Engineering Sciences consultation report in 1967, which sought to explore the difficulties and available alternatives in fimancing sewer construction. ${ }^{212}$ The report distinguished between what it called "local" and "regional" facilities. ${ }^{213}$ It held that local facilities-laterals, collectors, mains, and the like-were a local responsibility that ought to be met

208. Id. The point is drawn from J. Sax, Water Law, Planning and Policy 398 (1968).

209. See generally Dunkelberger, The Federal Government's Role in Regulating Water Pollution Under the Federal Water Quality Act of 1965, 3 NAT. REs. LAW. 3 (1970).

210. R.M. Sinith, Nevada Governor's Natural Resources Council, Problems of Lake Tahoe 18, 1967.

211. For a striking analysis of the economic issues in pollution control see $\mathrm{J}$. Dales, Pollution, Property and Prices (1968).

212. See Engineering Sciences, Inc., A Regional Program for the Protection of Water Resources in the Lake Tahoe-Truckee Rrver Basin (1967) thereinafter cited as Regional Program].

213. Id. at $\mathrm{V}-2$. 
through special assessments on local people. The report assumed that general obligation bonds would be used to defray the cost of regional facilities-interceptors, treatment facilities and disposal works. It estimated that 10 percent of assessed property valuation was a reasonable maximum indebtedness under these bonds. On this basis the report concluded:

[I]t will be necessary to supplement local financial resources by an infusion of outside funds of considerable magnitude. In other words, if Lake Tahoe is to be truly considered an asset of regional and national value beyond its local value, then financing from outside sources is in order for assisting im solving the problem. ${ }^{214}$

More particularly it found that the basin had regional facilities costing $21,575,300$ dollars either existing or then under construction. It found additional regional facilities capable of handling 50 percent of the ultimate sewage flow would cost another 28,076,000 dollars. And it found that facilities to handle the remainder would cost another $17,525,000$ dollars. ${ }^{215}$

The immediate question thus beeomes where one can find the initial 28 million dollars. ${ }^{216}$ Using the ten percent indebtedness figure, the Survey concluded the local agencies were some $22,300,000$ dollars short of the available capability. ${ }^{217}$ The report also concluded that "[t]o achieve these levels of outside assistance will require a special prograin beyond those now authorized by existing State and Federal legislation."218 The report reviewed several possible sources of funds-notably, the Federal Water Pollution Control Act; ${ }^{210}$ the Public Works and Economic Development Act of $1965 ;{ }^{220}$ the Housing and Urban Development Act of $1965 ; 221$ the Consolidated Farmers Home Administration Act; ${ }^{222}$ and possible special state and federal legislation. The report paid most attention to an alternative involving $10,058,000$ dollars in P.L. 660 funds; 8,180,000 dollars in local bond money and $12,242,000$ dollars in special federal loans and grants. ${ }^{223}$

214. Id. at V-9.

215. Id. at V-5 (Table V-4).

216. The report focused primary attention on financing regional facilities to cope with the first 50 percent, not merely because that sewage outflow was closer in time but also because the increased tax base created by home building would inake the costs of the later sewer-building easier to bear.

217. Regional Program, supra note 212, at V-8 (Table V-6).

218. Id. at V-9.

219. 33 U.S.C. $\$ \S 466-466$ n (Supp. V, 1970), as amended, Water Quality Improvement Act of 1970 , Pub. L. No. 91-224, 84 Stat. 91 (to be codified as 33 U.S.C. $\S \S 1151-75)$.

220. 42 U.S.C. $\S \S 3121-226$ (Supp. V, 1970).

221. Id. $\S \S 3531-37$.

222. Id. §§ 1921-29.

223. See Alternative 2, Regronal Program, supra note 212, at V-11. 
As a matter of fact, Tahoe has received very substantial infusions of state and federal money. A study by the Federal Water Quality Administration concludes that there was $45,500,000$ dollars of sewer spending in the basin in the period from 1965 to 1969 , of which $11,895,000$ dollars came from federal government grants, and 6,370,000 dollars from the state loans. ${ }^{224}$ It is quite clear, then, that the problem has been treated, as the 1967 report recommended, as of local, state and national concern.

While the case for outside funding is persuasive, it is not coinpletely self-evident that this was or is the best way to handle the financial problems of the basm. The argument, to repeat, rests on the premise that sewer-building is expensive, and the conclusion that, therefore, outsiders should help pay for it. Both of these points deserve further scrutiny.

As to the notion that sewer-building is beyond the capability of local people, there is soine ambiguity in the assertion itself. Current estimates of the cost of providing sewer service to an individual home in the Tahoe area run as high as 8,000 dollars.225 Clearly this is not cheap. It is undoubtedly higher than flatland sewer costs, and it is aggravated by the fact that the prospective payer often is using his lake hoine only a few months a year, and by the fact that he is probably paying for another sewer someplace else. But saying that sewer costs in the Tahoe basin are inordinately expensive, is not to say that the resident cannot afford the cost. If someone had decided ten years ago that all Tahoe homes must be sewered but that no outsider should have to pay any part of the cost, all that would have happened is that home-building in the basin would have been much more costly; and hence probably not nearly so many homes would have been built. The speculative possibilities of land developinent in the basin might have been less attractive, and hence land values throughout the basin might have been depressed.

Moreover, even conceding that the public at large should pay a great sum to preserve Lake Tahoe, it is not at all clear that the pay-

224. Federal Water Quality Administration Pacific Southwest Region, Lake Tahoe 1970 Status Report On Water Quality Management, July 1970 (unpublished). The 11 million dollar figure imcludes 6,358,000 dollars from the Federal Water Quality Administration aud 3,253,000 dollars from the Economic Developmeut Admimistration or a total of 9,611,000 dollars for "regional" facilities. It imcludes another 2,284,000 dollars from the U.S. Forest Service to serve its own facilities in the South Tahoe area. Aside from the sewer building money, the report indicated that the Federal Water Quality Administration has also contributed 1,738,000 dollars in funds for water quality research at Tahoe in recent years.

225. Interview with William Layton, Treasurer-Manager, Tahoe City Public Utilities District, in Tahoe City, Calif., Aug. 14, 1970. 
ment should have taken the form of subsidies to sewage facilities. Thus perhaps the question should lave been, not whether it was desirable to expand 18.2 million dollars in state and federal funds for Tahoe basin sewage facilities; but rather, whether it would have been more desirable to channel the funds to other projects: for example, the purcliase of land for public recreational use.

It will be argued that a totally local approach to sewer financing is unworkable since the cost of regional disposal facilities remains relatively constant for any number of people; and that the whole problem now is that there aren't enough people to support the necessary capital outlay. By restricting the number of people in the basin still further-so this reasoning would go-one quickly gets to the point where private residential construction is priced completely out of the market. But there is a disputable premise concealed here. The prevailing argument for subsidy assumes that extensive developinent is desirable. To the outside taxpayer being asked to pay a subsidy the case for development is not obvious or urgent. It raises the possibility that Tahoe as a scenic resource will one day lose its appeal; and the proposal for subsidy aggravates that threat by imposing a claim on general revenues. These outside taxpayers might prefer no developnient at all. If they are to concede that there will be sonie development, and that they will support it, then surely they deserve sonie voice in developnient pohicy as a trade-off for their investnient. Concededly, the general public through state and federal government presently has some voice in developnent policy. But it is impossible to say whether it is a fair recompense. The question should be faced explicitly: surprisingly, it rarely lias been.

There is one final irony in the sewer-financing situation, separate from but related to the previous point. That is, the sewer program as now constituted positively encourages extensive developnient in at least two ways. First, the very presence of good sewer facilities helps to legitimatize development pressures. Second, the capital cost of export facilities is so great that it needs great numbers of customers to justify it. Put another way, the cost of sewer lines themselves-even apart from export facilities-is so large as to force the breakup of large parcels previously reserved for single family use. A 1968 survey put it:

[W] ithout sewers, development and population growth are hampered; but without significant development, major sewer construction is not warranted. It is anticipated that the completion of the initial phase will spur the growth in the adjacent areas, and this growth will then provide the basis for further project expansion. ${ }^{226}$

226. Creegan \& D'Angelo, supra note 69 , at 44 . A similar point is made in a staff 


\section{III}

\section{SEDIMENTATION}

\section{A. The Problem}

The late afternoon of August 25, 1967, brought one of those bursts of summer thundershowers that are common in the Sierra. ${ }^{227}$ Measured rainfall in the Tahoe area varied from .10 of an imch to 1.31 inches but was apparently heaviest at the higher altitudes like the upper tip of the watershed of Second Creek above Incline Village at the north end of the lake. In these steep and unforested uplands the rain triggered sheet and rill erosion that flushed into the creek channel at an altitude of about 9,000 feet. The abrasive mixure of water and sediment scoured the channel to bedrock, carrying off more sediment froin earlier storms and building the streamflow into a vicious mass. At 6,540 feet, the mass hit Second Creek bridge and backfilled behind a culvert until it overtopped the roadway and spilled out into the channel, damaging a house. Further downstream, the inud flowed onto state route 27 and diverged west from the channel to the roadway. At the junction of state routes 27 and 28, the mud veered off the highway through Crystal Shores Villas, an apartment project, where it damaged more buildings before petering out around the lake shore.

The Second Creek inudflow epitomizes the major man-made and natural problems associated with the other great threat to Tahoe's clarity; sedimentation, a process whicli carries dirty water and nutrients into the lake, stripping away vegetation needed to absorb nutrients and to keep soil in place. Besides dannaging buildings, the Second Creek inudflow deposited some 50,000 cubic yards of mud over 16 acres of ground, and another, but apparently lesser, batch im the lake itself. Such mudflows are natural in origin: the rain and erosion would be there even if no men ever came to Tahoe. But they are clearly aggravated by the presence of man. Happily, the thunderclouds of this particular storm had a silver lining: the inudflow alerted highway planners to the need for large culverts to prevent backfills and spills around the channel. Despite this and other warnings, ${ }^{28}$ however, the

paper at the Tahoe Regional Planning Agency dated Aug. 5, 1970, and by Vaughn Burlingham, project manager for Boise Cascade's Incline Village project at Tahoe in the Reno Evening Gazette, Nov. 5, 1969, at 7, col. 1. The Engineering Sciences Survey itself concedes that sewer development will not be so costly in the final stages after there is a large local tax base to sustam it.

227. The account of the Second Creek mudflow is based on Glancy, A Mudflow in the Second Creek Drainage, Lake Tahoe Basin, Nevada, and Its Relation to Sedimentation and Urbanization, U.S. Geological Survey Professional Paper 650-C, at 195-200 (1969).

228. For other discussions of the sediment problem see RESOURCES AGENCY, CAL. Dep't of Conservation, Division of Soll Conservation, Sedimentation \& ERosion 
situation has deteriorated to the point where human activities that provoke sedimentation are probably the chief threat to the water quality of Lake Tahoe. ${ }^{229}$

The inajor question is wliy these warnings have not been leeded. One reason may be inadequate recognition of the problem; for, while it is true that there has been ready understanding of the sediment problein at a sophisticated level, it is by no ineans clear that people who build or buy loones in the basin are aware of the problem. There remains some dispute over the relation of luman activity to the production of sediment. If sewage is getting into the lake, it is fairly obvious and fairly generally understood that the presence of human beings and human activity has something to do with it. But when a great sleet of mud slides into the lake, there is a basic question as to whether any human being at all is responsible, or if so, to what extent.

As a corollary, even when it is clear that liuman beings and sediment are related, many sediment problems remain peculiarly elusive of control. Much of the human activity that creates the problem is sporadic and transitory: for example, construction activities where the damage is over and done with before the control activity can catch up with it. And even assuring that adequate legal control can be devised, sophisticated technology is required to effect even partial solutions. This last point may come clearer with a review of building controls in just one basin county-Placer, in California, where both construction and control are extensive. Some of Placer County's requirements may be described as procedural: for example the county requires submission of an improvement plan and geological and environmental study prepared by professional consultants with emphasis on construction aspects that may cause erosion. ${ }^{230}$ These reports lave resulted in buildings beimg relocated or eliminated altogether. ${ }^{231}$ Similarly, the county requires builders accurately to establish the high water line of the lake or the floodplaim of any nearby stream or creek. ${ }^{232}$

Other requirements may be described as substantive construction

IN THE UPPER TRUCKeE RIVER aNd TROUT CReEK Watershed (1969); COMPILATION OF INFORMATION, supra note 95, at 2; WILSEY, HAM \& BLAIR, LAKE TAHOE 1980 REgIONAL PLAN (1964).

229. This is the thrust of most, though not all, of the testimony at the Public Conference on the Lake Tahoe Siltation Problem, held July 17, 1970, at South Lake Tahoe by the State Water Resources Control Board and the California Regional Water Quality Control Board, Lahontan Region.

230. See Improvement Standards and Specifications of Placer County, Preparation of Plans $\$$ II [hereinafter cited as Improvement Standards].

231. Statement of Roger Imsdahl, Planning Engineer, Placer County Department of Public Works, presented at the Lahontan Regional Water Quality Control Board Siltation Conference July 17, 1970, at 3, [hereinafter cited as Imsdahl Statement].

232. Placer County, CaL., Ordinances ch. 19, \$ 10.125(4)(k). 
controls based on judgments about what will or will not control siltation. For example the county requires all drainage collected within the development tract to be conveyed to a natural stream or conduit that itself flows to a natural stream. ${ }^{233}$ Again, the county requires in most cases that all construction be completed within a single construction season, or, failing that, that elaborate winterizing programs be undertaken. ${ }^{234}$ The county has been experimenting with sophisticated siltation-control devices in consultation with the State Division of Soil Conservation, a field in which, says an official, "we feel, however, that we still have a lot to learn . . ..9235 Concededly, siltation control is not impossible of accomplishment. But is not completely clear that Placer County's efforts are enough. Ultimately, the solutions require informed application by the very bulldozer operators themselves, and to expect the sophisticated performance the requirements envision, from people who do not recognize that there is a problem in any sense, is to expect a great deal.

\section{B. Control Through Water Quality Enforcement}

In the past the Lahontan Regional Water Quality Control Board dealt with the problein of sedimentation at length in the form of recommendations urging action by other authorities. ${ }^{23}$ Impliedly, the Board took the position that it did not have the power to meet major siltation problems on its own. Thus, the Board urged legislation restricting shoreline construction; ${ }^{237}$ and controlling construction with a potential for causing turbidity in the lake. ${ }^{238}$ In each case, the Board promised to "engage in community activities and otherwise direct public awareness to the need for and encourage public support of" these activities. ${ }^{239}$

More recently, the Board lias embarked on a much more extensive program of control. After a well-publicized "review" of siltation problems, ${ }^{240}$ the Board voted to impose waste discharge requirements

233. Improvement Standards, supra note $230, \$ 5.01$ (storm drainage).

234. Imsdahl Statement, supra note 231 , at 5 .

235. Id. at 4 .

236. See generally Lake Tahoe Water Quality Control Policy, supra note 201; Lake Talıoe Water Quakity Control Policy, Addendum Regarding Implementation, supra note 135.

237. Lake Tahoe Water Quality Control Policy, supra note 201, at 17.

238. Id. at 18.

239. Id. at 18-19. This promise was made in regard to both shoreline construction [id. at 18] and factors causing turbidity. Id. at 19.

240. See Minutes of State Water Resources Control Board and California Regional Water Quality Control Board, Lahontan Region, Public Conference on the Lake Taloe Siltation Problem, July 17, 1970, on file in the Lahontan Regional Water Quality Control Board office, Bishop, Cal.; Minutes of California Regional Water Quality Con- 
on individual homeowners in subdivisions alleged to be causing siltation. ${ }^{241}$ The Board staff also filed a clean-up order, authorized under the Porter-Cologne Act, to force clean-up in an individual situation. ${ }^{242}$ Finally, the Board noved to adopt an addendum to its water quality control plan to contend with the shit problem. ${ }^{243}$

A number of problems remain unsolved at this point. The fundamental question of whether "sediment" is included within the relevant definitions of "pollution" may remain vulnerable to hitigation. ${ }^{244}$ Waste discharge requirements, while they may be useful in severe cases, cannot practically be imposed on every potential discharger in the basin. The clean-up order, while useful after the fact in individual situations, can hardly function as an effective policy tool. An amendment to the water quality plan might best serve to publicize the problem. But there appears to be no precedent for direct independent enforcement of the plan. ${ }^{245}$ Thus, exactly how useful direct enforcement would be remains at least problennatical. Ultimately, it may be necessary for the Board to seek new legislation to clarify its role and to equip it with means nore suited to the situation. ${ }^{240}$ Perhaps what is most significant is that im the face of these ambiguities, the Board is proceeding, and apparently accomplishing something. Once agam, as with sewage, the crucial issue may not be the extent of the Board's actual power, but its willingness to act.

trol Board, Lahontan Region, 31st Special Meeting, August 13, 1970, on file in the Lahontan Regional Water Quality Control Board office, Bishop, Cal.

241. See Minutes of the 31st Special Meeting, supra note 240.

242. California Regional Water Quality Control Board, Clean-up Order No. 70-1 (July 27, 1970).

243. Formal adoption as part of the policy requires action not only by state agencies but by the Federal Water Quality Administration as well. See 33 U.S.C. $\$ 466 \mathrm{~g}$ (c) (Supp. V, 1970), as amended, Water Quality Improvement Act of 1970, Pub. L. No. 91-224, \$112, 84 Stat. 114 (to be codified as 33 U.S.C. $\$ 1160$ (c)).

244. The relevant language in the Porter-Cologne Act defines waste to include "sewage and any and all other waste substances, liquid, solid, gaseous, or radioactive, associated with human habitation, or of human or animal origin, or from any producmg, manufacturing or proccssing operation of whatever nature." CAL. WATER CODB $\S 13050$ (d) (West Supp. 1971). For an expansive reading of the former Dickey Act definition see 26 Op. Cal. AtT'y. Gen. 88 (1955); 27 Op. Cal. Att'y. Gen. 182 (1956).

245. The Porter-Cologne Act nowhere specifically declares that a plan is independently enforceable without the imposition of a waste discharge requirement. CAL. WATER CODE $\$ 13243$ (West Supp. 1971) does provide that a board may, in a plan, "specify certain conditions or areas where the discharge of waste, or certain types of waste, will not be pernitted." CAL. WATER CODE $§ 13301$ (West Supp. 1971) provides for the issuance of cease and desist orders against violations of "requirements or discharge prohibitions . . . ." It is conceivable that the "prohibitions" referred to in section 13301 are the "certain areas" referred to in section 13243. But a more explicit mandate would surely be less likely to provoke litigation.

246. This possibility evidently has entered the Board's mind. See Agenda Item 7-E, Meeting of the Lahontan Regional Water Quality Control Board, Apr. 23, 1970, on file im Board office, Bishop, Cal. 


\section{Aid Through Soil Conservation}

Since 1968, the Nevada portion of the basin has been included in the Tahoe-Verdi Soil Conservation District, an entity created under the Nevada Soil Conservation District Law, in conformity with the Federal Soil Conservation Law. ${ }^{247}$ The District functions with staff support from the Soil Conservation Service ${ }^{248}$ which provides technical information on sediment and erosion control to county commissioners considering subdivision plans, and to drafters of the Nevada Tahoe Regional Plan. It also is completing a basin soil survey and carrying out a plant materials testing program to identify plants useful in conserving soil. ${ }^{249}$ The Tahoe area is also part of a larger and more extensive river basin study being carried out by the Service. ${ }^{250}$ California counties in the basin also have used the Nevada district's technical advice in land use control, since no California district is presently active in soil conservation work. ${ }^{251}$

Soil conservationists themselves-uninhibited by the fact that they have no significant "regulatory" role-are convinced that they can make significant contributions to sedimentation control through such technical advice. Clearly this argument is beginning to take root in the basin.

Under the circumstances, it is tantalizing to speculate on why soil conservation technical aid has not beeen more evident in the basin in the past. Part of the answer must be that there has been little interest or initiative from inside the basin. Another part may be that the soil conservation service itself is changing. Until recently, it was an agency with an agricultural constituency and almost exclusively agricultural interests. Only recently has it sought to re-establish itself on a inore general basis. ${ }^{252}$

IV

\section{OTHER THREATS TO TAHOE WATER QUALITY}

Sewage and sediment are not the only hazards to water quality at

247. 16 U.S.C. $\$ 590 \mathrm{a}-q$ (1964); NEV. REV. STAT. ch. 548 (1967).

248. Interview with William Dunning, District Conservationist, in Minden, Nevada, Aug. 18, 1970.

249. Letter from T.P. Helseth, State Conservatiomist to the author, July 15, 1970, on file with the California Law Review and the Ecology Law Quarterly.

250. Id.

251. Joint Study Comm. Report, supra note 8, at 45.

252. "Unfortunately, USDA agencies and soil conservation districts have often been slow to recognize their own responsibilities for erosion and sediment problems arising from non-agricultural activities." Editorial, USDA's Role in Agricultural Pollution Abatement, J. Sol \& WATER Conservatron, May-June 1970, at 82.

Two possible reasons for this new interest may be the decreasing political power base available in agriculture and enhanced public interest in the environment. 
Lake Tahoe: a number of other human activities present lesser hazards, of which a few require at least passing mention.

\section{A. Shoreline Construction}

Construction along the shoreline of the lake creates threats to water quality that might be treated as part of the sediment problem, ${ }^{263}$ but are perhaps inore conveniently treated separately for several reasons. First, shoreline construction creates problems beyond simple turbidity. Poorly designed breakwaters and marinas tend to restrict circulation and provide incubators for algae. These imcubators tend to be located on shore where they are most obvious; and from time to time they are flushed out providing more fresh water for incubation and degrading the quality of the rest of the lake.

Administratively, too, shoreline construction has become a somewhat separate problem. The state of Nevada claims title to Lake Tahoe to the high-water mark, putting control of construction there in the State Department of Health and Welfare, which has sought to restrict most construction activity. ${ }^{254}$ California claims title only to the low-water line; and responsibility for construction between low and high water has thus developed chiefly on the U.S. Army Corps of Engineers. ${ }^{265}$

The Engineers may just now have arrived at a critical milestone im the history of their supervision. Since 1899 , a statute has prohibited obstruction of navigable waters without pernission of the Secretary of the Army. ${ }^{256}$ Regulations promulgated under the statute im 1968 defined a mandate for issumg permits that was somewhat broader than a superficial reading of the statute might have suggested. $^{257}$ Thus, the regulations provide that permit decisions will be nrade "on an evaluation of all relevant factors, including the effect of the proposed work on navigation, fish and wildlife, conservation, pollution, aesthetics, ecology, and the general public interest

253. See Lake Tahoe Water Quality Control Policy, supra note 201, at 17.

254. See NEv. REv. STAT., \& 445.080(3) (1967), which prohibits construction or alteration of the Tahoe shoreline below the high water elevation without written permission from the Health Division. The basis of this provision is more tenuous than one might suspect. In NEv. REv. STAT. ch. 537 (1967) the Nevada Legislature has elaimed title to the high water mark beneath certain navigable waterways, but Tahoe is not one of thein. Whether Nev. Rev. STAт. $\$ 445.080(3)$ (1967) can be read as itself justifying such a claim for Tahoe would seem at least open to question. With regard to a similar situation on the Carson River, the Attorney General has expressed the opinion that the state holds only to the low water line. OP. NEv. ATT'Y GEN. No. 632 (1970).

255. Cal. Crv. Code $§ 830$ (West 1954); 30 Op. CAL. Att'y GeN. 262, 269 (1957).

256. 33 U.S.C. $\$ 403$ (1964).

257. 33 C.F.R. $\$ 209$ (1970). 
. . . ."258 The statute itself, directed as it is to navigational hazards, would hardly seem to support the variety of other considerations in the regulations. ${ }^{259}$

In any event, however, the Corps' hand may have been strengthened by the Water and Environmental Quality Improvement Act of $1970 .^{200}$ The Act explicitly provides that any applicant for a federal permit for any activity which may result in a discharge to navigable waters shall provide evidence that the activity will not violate relevant water quality standards. ${ }^{261}$ Thus, the Act would seem to have removed a major source of ambiguity as to the extent of the Corps' powers.

\section{B. Solid Waste}

Expert opinion has varied over the extent to which solid wastegarbage-is a source of nutrients that threaten the lake. ${ }^{262}$ A variety of public agencies liave and continue to press for the removal of all solid wastes from the basin. The Laliontan Board as part of its 1966 water quality control policy issued a prohibition against discharge to the surface waters of the basin. ${ }^{263}$ It also established the policy that there should be no discharge imside the basin even if outside the surface waters. ${ }^{24}$ But as to discharge outside surface waters the Board said only that it "encourages and will support" state and local action to enforce its policy, thus impliedly conceding it had no direct authority in the matter. ${ }^{265}$ The California State Board of Health urged "the early completion of export systems for both sewage and garbage waste" in 1968..$^{268}$ While solid wastes were explicitly exempted from the legislative export deadline, solid waste export continues to have sup-

258. Id. § 209.120.

259. Discussing a similar section last summer, the General Counsel of the Army, who is also special assistant to the Secretary of the Army for civil functions, acknowledged that there were "uncertainties" about the Secretary's power to regulate nonnavigation matters under navigation legislation. He said he felt the Secretary did have the power, however. See Statement of Robert E. Jordan, Hearings on the Effects of Mercury Before the Subcomm. on Energy, Natural Resources and the Environment of the Senate Comm. on Commerce, 91st Cong., 2d Sess. 423 (1970).

260. Water Quality Improvement Act of 1970, Pub. L. No. 91-224, 84 Stat. 91 (to be codified as 33 U.S.C. $\S \S 1151-75$ ).

261. Id. §§ 102-03, 84 Stat. 107.

262. See, e.g., Bureau of Vector Control and Solm Waste Management, Cal. Dep't of Public Health, A Study of Future Sold Waste Management iN the LaKe Tahoe AREa II-1 (1969) [hereinafter cited as Sold Waste StUdy]; CoMPREHENSIVE STUDY, supra note 19, at 94.

263. Lake Talioe Water Quality Control Policy, supra note 201. at 13.

264. Id. at 14.

265. Id.

266. SoLID WASTE STUDY, supra note 262, at I-1. 
port as a policy goal. ${ }^{267}$ Garbage export was included among the "conclusions and recommendations" of the Federal Water Quality Control Conference in $1966 .{ }^{268}$ The response to these various mandates was about the same as the response to the mandates on sewage. Garbage is not all being exported now, but the job seems nearer to being done than it might be without diverse public pressure.

Again as with sewage, while mandates on solid waste may be laid down by outside agencies, ultimate effectuation depends on local effort. Local governments, in turn, have delegated the task to private contractors operating under franchises. A survey by the California State Board of Health found that as of June 1969, there were five major disposal areas serving the Tahoe Basin, of which only one was outside the basin. More important, in the view of the Health Board, was that in most areas, only a fraction of the customers signed up for collection service. It urged the local districts to press for landfill sites outside the basin. It recommended possible particular sites, and suggested means of carrying out the recommendations. ${ }^{260}$

\section{Fertilizer}

Of all potential water quality problems at Talioe, none yet has so coinpletely defied rational solution as the question of fertilizer. Engineers' studies have forecast that by the year 2010 fertilizers could be adding lialf as much nitrogen to the lake as natural rainfall. 270 As early as 1961, the Public Health Service suggested that the use of fertilizers might ultimately have to be banned, ${ }^{271}$ but as of now no ban is in effect or in the offing. In fact, the contrary is true. Some public decisions have increased the amount of fertilizer used in the basin. Prior to the beginning of its sewage export scheme this year, the Incline General Improvement District had been spraying treated effluent on community golf links. Lacking the treated effluent, the District will have to import fertilizer to replace the lost nutrients. ${ }^{272}$ Similarly the Heavenly Valley Skiing operation, under pressure froin both the Forest Service and the Lahontan Board, has begun a program of replanting to slow sedimentation. Company officials report that it will be necessary to add fertilizer to get plantings to take root. ${ }^{278}$

267. Id. at V-4.

268. Conference Proceedings, supra note 133, at 299.

269. See Solm WASTE STUDY, supra note 262.

270. J. Legget \& F. McLaren, Lahontan Regional Water Quality Control Board, California Resources Agency, The Lake Tahoe Water Quality Problem: History and Prospectus 7, June 1968 (Table 2).

271. Cf. Compilation of Information, supra note 95, at 2.

272. Interview with W.W. White, Manager, Incline General Improvement District, iu Incline Village, Nev., Aug. 14, 1970.

273. Lahontan Regional Water Quality Control Board meeting, Aug. 13, 1970 (author's notes). 


\section{THE RELATION OF WATER QUALITY AND WATER QUANTITY}

At the crest of the Sierras, Tahoe reposes rich in natural snow and rainfall. Less than 20 miles away begins the vast and arid Humboldt basin. The basin has long depended on the mountains for water, and Tahoe has become part of an elaborate reservoir system serving downstream users. When quantity is in short supply, some dispute over beneficial uses is inevitable. Tahoe has frequently been embroiled in such disputes. ${ }^{274}$ From time to time, they have threatened Tahoe's role as a scenic treasure.

There have been periodic proposals to lower the lake level at Tahoe to take vast quantities of water for supply elsewhere. ${ }^{275}$ Oddly enough, the first of these came not froni Nevada at all, but from California. In 1866, a proposal to run an aqueduct through a mountain tunnel to San Francisco failed when the Mayor of San Francisco refused to sign the financing ordinance. A renewal of the scheme in 1903, again defeated, helped to focus interest on the competing Nevada reclaination scheme. ${ }^{278}$ In 1887 the idea of tunneling to $\mathrm{Ne}$ vada to increase the flow of the Truckee River was considered but dropped. ${ }^{277}$ Between 1909 and 1913, the U.S. Government proposed a series of tunnelling and dredging scheines, at least one of which would have lowered the lake so far as to close the entrance to Emerald Bay, but public opposition leaded these off. ${ }^{278}$ Other threats were more dramatic. In 1919 and again in 1930, Nevada farmers showed up at the mouth of the Truckee ready to cut a channel to increase the flow. ${ }^{270}$ Threatened liarm to downstream users produced coinpromise

274. The best general survey of Lake Tahoe water use is in 30 Op. CAI. ATT'Y Gen. 262 (1957). See also M. Glass, Water for Nevada, The Reclamation ConTROVERSY 1885-1902 (1964); G. HINKLE \& B. HINKLE, supra note 18, at 250-350; R. Lillard, Desert Challenge: AN INTERPRetation of NeVAda $61-73$ (1942).

Water from Tahoe flows north up the Truckee River through Reno and Sparks, Nevada, and into Pyramid Lake on the Paiute Indian reservation. Since 1908, Truckee River water has also been diverted to the Newlands Project, first of the U.S. Bureau of Reclamation's great water projects, now run by the Truckee-Carson Irrigation District. The Newlands Project also gets water from the Carson River, which rises in the Sierras south of Tahoe and flows north through Carson Valley several miles east of the lake.

The engineers who created the Newlands Project underestimated the amount of water necessary to irrigate these lands, and overestimated the amount available. See R. LiLlaro, supra at 64 . Practically speaking, there has never been enough water to satisfy both the aspirations of the farmers in the Newlands Project area and the Indians at Pyramid Lake. This has been and remains a source of bitterness.

275. G. HinkLE \& B. HiNkLE, supra note 18, at 285-86, 292-93.

276. Id. at 337 .

277. M. GLASs, supra note 274 , at 21 .

278. R. LILLARD, supra note 274 , at $68-69$.

279. G. HnNKLE \& B. HrNKLE, supra note 18, at 341-43. 
schemes allowing pumping from the lake in four dry years in the 1920's and 1930 's. ${ }^{280}$

Efforts to preserve the lake level have come not exclusively from the littoral owners. Downstream users in each of the two states have resisted competing claims froin the other. Thus in 1870, the Virginia City Territorial Enterprise warned that Californias who expected to transport water to San Francisco liad better plan to raise and equip an army if they intended to carry out their scheme. ${ }^{281}$ And the 1903 dispute took on the character of an interstate conflict. ${ }^{282}$

Despite these efforts to use lake water, the cffective rim of the lake has been and remains 6,223 feet above sea level, marked by a brass bolt on the face of a dam at the entrance to the Truckee. ${ }^{283}$ Donner Lumber and Boom Co. acquired a state permit to build that dam in 1870.284 The United States took it by condemnation on behalf of the Newlands Project in 1915, and affirmed the 6,223 foot level in a consent decree entered as a part of that action. ${ }^{285}$

Just as the littoral landowners have resisted schemes to reduce the lake level, so from time to time they have opposed plans to let it rise too high, contending that this would cause damage to shoreline property. The 1915 decree did not settle the high-water question, but it was fixed at 6,229.1 above sea level as part of the Truckee River Agreement of 1935, a negotiated agreement between the United States and various downstream users-not including either the states of California or Nevada themselves. ${ }^{288}$

Both low and high water levels were reaffirmed in 1944 in United States v. Orr Water Ditch $\mathrm{Co}_{0 .}{ }^{287}$ an equity action adjudicating rights of all users of Truckee River water except the Lake Tahoe littoral landowners and the riparian owners in California. This decree, which has become known as the Truckee River Final Decree, also provided that the United States has the right to loold and store all water entering Lake Tahoe up to 3,000 cubic feet per second of flow. This is equivalent to over 2 million acre-feet per year. Since the permissible lake levels allow a storage capacity of only some 732,000 acre-feet, the

280. 30 OP. CAI. ATT'Y GEN. 262, 266 (1957).

281. G. HINKLE \& B. HINKLE, supra note 18, at 292.

282. R. LILLARD, supra note 274, at 64 .

283. U.S. Bureau of Reclamation and U.S. ARMY Corps of Engineers, Reconnaissance Appraisal of possible Ways to Relieve Flood Damage Around Lake TAHOE 1 (1957).

284. Ch. 513, [1869-70] Cal. Stats. 771.

285. United States v. Truckee River Gen. Elec. Co., Civil No. 14861 (N.D. Cal. 1915).

286. See 30 Or. Cal. ATT'Y Gen. 262, 266 (1957).

287. Equity No. A3 (D. Nev. 1944). 
decree effectively appropriates all the water conceivably available from Tahoe for downstream users. The California Attorney General in 1957 expressed the opinion that littoral landowners once possessed a right of action against those who mamipulated lake water levels for storage, but apparently had lost it by the running of the statute of limitations or laches. ${ }^{288}$ Thus it would seem that the littoral landowners have no clear authority for taking water between 6,223 and $6,229.1$ feet, and more particularly, no right to pump it out of the Tahoe basin in such a way that it becomes unavailable for downstream use in the Truckee basin. Simce export is a key to Tahoe's water-purity plan, the potential conflict between downstream users and those who want to preserve the lake's purity is obvious.

In a separate initiative, the two states began negotiating in 1955 to create an interstate compact allocating the waters of the Truckee and the Carson and the related Walker river system between them. ${ }^{289}$ The central question was how much water would be allowed for use in the Tahoe basin, and the related question of whether export of sewage effluent ought to be permitted. The drafters early agreed to allocate 34,000 acre-feet annually for basin use. ${ }^{290}$ But the export question was harder to solve. There is no evidence of great enthusiasm for export in the negotiators' minutes. Such attention as there was evidently grew out of recognition that export was being discussed elsewhere and might simply have to be recognized. Objections to export fell roughly into two groups: First, export of sewage effluent might mean a net loss of water available downstream; ${ }^{291}$ and second, the quality of downstream waters might be threatened. ${ }^{292}$

The drafters considered various approaches to the problem in the

288. 30 Op. CAL. ATT'Y GEN. 262 (1957).

289. Various issues involving water quality have figured in negotiations from time to time. The proposed draft compact foresees a permanent commission to supervise water allocation in the affected area. At one time drafters of the compact foresaw giving the permanent commission power to oversee water quality standards. See Minutes of the 18th meeting, Sept. 2-3, 1959, at 7. Minutes of the commission are on file at the Water Resources Archive, University of California at Berkeley, Cal. Staff drafting aides actually drafted a water quality standard for Tahoe. Minutes of the 26th meeting, Nov. 3-4, 1960, at 15. Standards were ultimately removed from the draft compact altogether. Minutes of the 58th meeting, Nov. 23, 1966, at 7-8, 12. The permanent assistant secretary of the commission recalls that "with the advent of the Federal Water Quality Act of 1965, it was realized that the compact would be duplicating water quality control efforts which could better be bandled at the state level under provisions of the Federal Water Quality Act." Letter from Robert B. Bond to the author, July 29, 1970, on file with the California Law Review and the Ecology Lav Quarterly.

290. Minutes of the 26th meeting, Nov. 3-4, 1960, at 15.

291. See, e.g., Minutes of the 21st meeting, Mar. 17-18, 1960, at 14-15.

292. See, e.g., Minutes of the $32 \mathrm{~d}$ meeting, Oct. 31, 1961, at 8. 
1960 's, but virtually all assumed that control of the problem would remain with a permanent commission administering the compact. On various occasions, outsiders inveighed against the proposed standards as providing too much leeway to the proposed cominission and threatening to jeopardize the export program. ${ }^{293}$ A draft was approved providing that no export should be made without permission of the proposed commission. ${ }^{294}$ It provided that export should be allowed when necessary to protect health, welfare and water quality in the basin. $^{295}$ But it also provided that no export should be permitted if detrimental to health and welfare of the area where the exported waters would be received. ${ }^{298}$ It becaine clear, however, that putting export under commission control was too widely regarded as a threat to the export scheme. ${ }^{287}$ In a revised version, the export question was left out of the compact altogether. The crucial language provides an allocation of 34,000 acre-feet per year to the basin and adds, "after use of the water allocated herein, neither export of the water from the Lake Tahoe Basin nor the reuse thereof prior to its return to the Lake is prohibited."208 That version of the compact passed the Nevada legislature in 1969.299 A modified version passed the California legislature in $1970 .^{300}$ The two together must win the approval of Congress before becoming effective however; and for reasons not directly related to Tahoe, that approval remains a matter of great doubt. ${ }^{301}$

Just as events outside the compact negotiations affected the compact, so the compact affected events outside. The Engineering Science Study in 1963 took note of the fact that its export plan threatened to restrict the amount of water available in the basin. Recognizing the demand for water downstream on the Truckee, it concluded that "trans-

293. See, e.g., Minutes of the $32 \mathrm{~d}$ meeting, Oct. 13, 1961, at 8-13; 36th meeting, Jan. 10-11, 1963, at 8-10.

294. California-Nevada Interstate Compact Concerning Waters of Lake Tahoe, Truckee River, Carson RIVER ANd Walker River Basins art. I, § 1 (draft of Oct. 29,1965 ) [hereinafter cited as CALIFoRNIA-NEVADA INTERSTATE COMPACT]. For a short summary of the Compact see Nev. Dep't of Conservation and Natural Resources, Compacts for the Future, Nevada-California, 1970.

295. CALIFORNiA-NEVADA INTERSTATE COMPACT, supra note $294, \S 2$.

296. Id.

297. R. Price, The Calffornta-Nevada Interstate Compact Commission, Third ANNUAL Resources AGENCY II-32 (1966).

298. Californta-Nevada INTterstate COMPaCT, supra note 294, art. V, $\S$ D (draft of July 25, 1968). See also minutes of the 60th meeting, Apr. 18, 1968, at 18-21.

299. NEV. REV. Stat. \$ 538.600 (1969).

300. CAL. WATER CODE $\$ \$ 5975-76$ (West 1971).

301. For the recent political history of the Compact, see CAL. Assembly Comm. on Water, a Report on the California-Nevada interstate Compact, Pursuant To H.R. 443 (1969). 
porting all flows for discharge to the Truckee River is the best overall solution to the problem." 302

Some contimuing potential conflicts over export remain. For example, three small Nevada general improvement districts are currently negotiating for an export site. One proposal is to transport the effluent through a plant in Douglas County, Nevada. An alternative plan would send it to South Lake Tahoe, California. It is conceivable that the South Lake Tahoe system will be able to recycle and reuse waste water in the future. The Nevada state engineer has said he will oppose a system that will allow the Nevada sewage to be used as recycled water in California unless Nevada is given appropriate credit. ${ }^{303}$

One final poimt on the relation of quantity to quality deserves attention. It is frequently suggested that the scarcity of water in the Tahoe basin represents an ultimate limit on basin development as a place to live or visit. ${ }^{304}$ This seems open to question. In the first place, the available evidence suggests that Tahoe water use is well within the limit on water diversions set forth by the compact, yet already beyond a population limit acceptable to the most ardent conservationists. ${ }^{305}$ On the other hand, local availability of water has never yet been a significant limit on developinent elsewhere in the arid west. Vast water-moving schemes have been developed to supply the needs of the Los Angeles area. The idea of importing water to Tahoe received intensive study within the past decade..$^{300}$ A study of the Truckee-Carson problem last year suggested that the ultimate solution may lie with proposals to import water froin the Northwest, Canada or Alaska. ${ }^{307}$ Even nore realistic is the possibility of reuse of water within the basin itself. ${ }^{308}$ The success of the South Tahoe purifica-

302. COMPREhENSIVE STUDY, supra note 19, at 128.

303. Interview with Roland Westergard, Nevada State Engineer, in Carson City, Nevada, July 2, 1970.

304. A congressional committee report earlier this year says "the threat of too little water for domestic uses is a growing one, and could become a major determinant of low many people the basin can allow to visit or live there." S. REP. No. 91-855, 91st Cong., 2d Sess. 2 (1970).

305. Division of Water Resources, Nevada Dep't of Conservation and Natural Resources, Summary of Water Filings and Uses of Water in the Nevada Portion of the LAKe TaHoe Basin (1970).

306. See U.S. Bureau of Reclamation, a Reconnarssance Appraisal of Ways to Develop a SUPplemental Water Supply for LARe Tahoe Basin (1964); U.S.

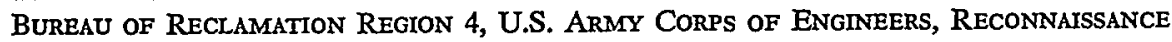
appraisal of Ways to Develop a Supplemental Water Supply for lake Tahoe BASIN (1967).

307. See Pyramid Lake Task Force, Basin Studies, Reports and Data TruckeeCarson River Basims, 1969 (prepared for presentation at a meeting Nov. 13, 1969, Reno, Nevada).

308. See Culp \& Moyer, Waste Water Reclamation and Export at South Tahoe, 
tion project suggests that it would be feasible, even aside from major population pressures. Thus it may appear that export was not the most logical long-run solution to the Tahoe sewage problem, after all.

\section{VI}

\section{REGIONAL PLANNING}

\section{A. The 1980 Plan}

Intertwined with the development of specific water quality control measures at Lake Tahoe has been an impulse for more general environmental control at the basin, which has commonly passed under the name of "regional planning." Since the problems of regional planning have received so much general attention at Tahoe, some review of the history of planning in the basm may help to add perspective to the discussion of water quality control. ${ }^{300}$

Significant regional planning activity in the basin began in the late 1950's. In this effort, as in the sewage disposal effort, perhaps the single most important figure was Joseph McDonald, the progenitor of the Lake Tahoe Area Council. ${ }^{319}$ Under the auspices of the Council, planning commissions from all the counties began meeting together in 1960, im a program of cooperative, if informal, consultation that continued through the decade. ${ }^{311}$ The Council also sponsored a "1980 Regional Plan," a documentary prospectus for the guidance of Tahoe growth published in $1964 . .^{312}$ The 1980 Plan yielded an unexampled fund of data about population, land use and related problems. It was distinctive in that it rejected what may be a central tenet of planning-growthmanship - the idea that planning ought to be geared for the maximum feasible economic growth. ${ }^{313}$ Specifically, the report projected that the basin could contain a maximum 1980 summertime population of 400,000 "at a relatively low standard of physical en-

Civil ENGineering, June, 1969, at 38, for the quality of South Taloe's export water. Reuse does not necessarily mean drinking. Reused water might be used for cooling, irrigation or the like, if objections to drinking proved insurmountable.

309. Local communities in the Taloe basin have long had, and retain, land use planning operations of their own. The regional effort has received nuch more public attention over the years, however.

310. See pt. II supra.

311. See Lake Taho Newsletter, supra note 29, Jan. 15, 1960.

312. See Tahoe Regional Planning Comm'ns of California and Nevada, Lake Tahoe 1980 Regional Plan, May 1964 [hereinafter cited as 1980 Plan]. The Plan was developed with 15,000 dollars in Fleischmann Foundation money, 15,000 dollars from local communities and 60,000 dollars from the Housing and Hoine Finance Agency.

313. The director of the study described it as "a little umique in respect to the fact that it's an attempt to have somewhat less than the economically generatable population. 
vironment."314 The report recommended rather that the basin strive to limit maximum 1980 summertime population to soine 300,000 .

It is difficult to evaluate the effect of the $1980 \mathrm{Plan}$, in part because it is difficult to say exactly what its goals were. Much of its language was general to the point of being horatory. The Plan document itself noted that the Plan as such had no authoritative force except as it might be employed by local officials, and then as "a general guide to their own planning programs and police power regulations, such as zoning and subdivision and controls."315 It probably performed this general guide function very well. It served to focus attention on the Tahoe problem as a general problem, and its data has proved a starting point for almost every analysis of basin problems since. And undoubtedly its general approach can be shown to have emerged in particular land use or developinent decisions.

Yet, the Plan itself speaks in gross terms and perhaps the best measures of success are also gross. And in this sense, the following point is imescapable: The Plan has not prevented extensive population growth and continued land subdivision. ${ }^{316}$ Perhaps even more suggestive of the success of planning, a background study for the Plan, found that in 1962, the entire Tahoe basin contained 15,675 vacant lots. ${ }^{317}$ No completely comprehensive survey has been made since, but one informal estimate puts the total at 15,000 for El Dorado County alone. ${ }^{318}$ El Dorado was the site of shightly inore than half of the vacant lots extant in 1962..19 This is not to say that all of the variations from the Plan have favored extensive development. The Plan also recommended a very extensive system of highways and parkways which has not inaterialized, probably more to the satisfaction of conservationists than developers. ${ }^{320}$

There are various reasons for this ambiguous record. In the first

Most plans, as you know, are quite the other way around." Statement of George Gatter in Hearings on Regional Planning, supra note 20, at 6.

314. Id.

315. 1980 Plan, supra note 312, at section on Implementing The General Plan.

316. 1970 Census figures are not available at this writing. There is some reason to believe they may not be as high as local advance estimates. The task of measuring population is coinplicated in a recreation area by the task of trying to keep straight wliat "population" means-whether permanent residents, vacationers, day visitors, or whiat. There can be no doubt that the recreational population of the Tahoe area is, by any measure, very substantial.

317. 1980 Plan, supra note 312 , at section on Land Use.

318. See El Dorado County Administrator for the Board of Supervisors, County Budget: Western Slope Versus Tahoe Basin, Mar. 31, 1970. A profile of assessed values in Attachment II counts 15,026 vacant residential lots of 24,563 developable lots in the basin.

319. 1980 Plan, supra note 312 , at section on Land Use.

320. Id. at section on Transportation. 
place, of course, the 1980 Plan never purported to put an iron-clad limit on development. Indeed, in the sense that it was unofficial it never purported to impose any limit at all. And planning agencies everywhere have had difficulties finding a viable political constituency, even under easier terms than these. ${ }^{321}$ More important, the Plan depended on local county and city officials for implementation, and there is very little to encourage county supervisors and city officials to adopt stringent restrictions on development. Indeed, if anything, the reverse is true: local officials favor development, and for intelligible economic motives. Best evidence of this may be a survey of taxes and expenditures prepared in early 1970 by the El Dorado, California, county administrator. ${ }^{322}$

The survey showed that 65 percent of the county population lived outside the basin, as against only 35 percent inside. Correspondingly, an analysis of expenditures showed that the outside population absorbed 54.1 percent and the inside, 23.3 percent, with 22.6 percent not susceptible of separation. Leaving out the non-separable portion the breakdown was 70 percent spent outside the basin, 30 percent within.

On the other hand only 48 percent of property tax collections came from outside the basin as opposed to 52 percent froin within. Thus, the basin area paid slightly more than half the property taxes and absorbed well less than half of the services.

The survey also showed that the county profited from the commercial and non-resident ownership property in the Tahoe vacation area. The probable consequences of such a situation are apparent enougl: with this sort of distribution, county government officials are under severe economic constraints to encourage, rather than limit, development in the Tahoe basin. The other three developed counties in the Tahoe basin slow the same geographical mix: large portions of territory outside the basin with quantities of commercial and nonresident ownership property inside. There is no reason to believe that the tax or political situation in any of these is materially different. ${ }^{323}$

This distribution has prompted interest in county reorganization in the basin area. Legislation calculated to ease the task of county

321. On the problems of planning, see R. Babcock, THE Zoning GAME (1966); E. Banfield \& J. Winson, City Politics 187-203 (1965); Reps, The Future of American Planning: Requiem or Renaissance?, PLANNING 1967, at 47.

322. See El Dorado County Adıninistrator for the Board of Supervisors, supra note 318.

323. For a suggestion that the same pattern prevails in Placer County, see Stateinent of James E. Williams, Placer County Administrator, in Placer County's Symposium on Lake Tahoe's Environment Workshop, Auburn, California 41, Apr. 3, 1970. 
reorganization has won approval in the past two California Legislatures, but each time was vetoed by the Governor. ${ }^{324}$ While it is true that one can conceive of a more coherent political and economic geography for the Tahoe basin, it does not necessarily follow that a simgle county restricted to the basin would inevitably be more solicitous of environmental values at the lake. If such a county were dominated by people who wanted to enjoy the lake for its environmental attractions only, then it might be. On the other liand, if it were dominated by people who wanted to profit from the recreation traffic, the impulse for conservation need not be as strong. There can be no doubt that in a crowded world, Tahoe could suffer froin a considerable aniount of environmental decay without losing its economic utility as a vacation spot.

\section{B. The Bi-State Agency}

In any event, the 1980 Plan did serve to focus attention on the Tahoe problem as a regional problem, and to promote interest in some sort of regional approach to general government in the area. ${ }^{325}$ In the context of this great general interest in the Tahoe basim, the two state legislatures, by concurrent action, created the Lake Tahoe Joint Study Committee to consider measures necessary to preserve Tahoe as a resource. ${ }^{326}$ The committee conducted a 15 -month public study and produced an elaborate report. ${ }^{327}$ It recommended the creation of "a governmental entity of general purposes but of limited functions, designed to supplement and coordinate, not to supplant or displace, the local governments of the Region." 328 The committee foresaw a bistate agency empowered to enforce land use control standards, and to act as an intermediary between local governments among themselves and with the federal government. ${ }^{329}$

The committee in its proposal spelled out the possible composition of the agency in some detail. It proposed a governing board of

324. A.B. 1941, Cal. Reg. Sess. (1969), vetoed, Sept. 4, 1969; A.B. 316, Cal. Reg. Sess. (1970), vetoed, Sept. 20, 1970.

325. See particularly the hearing before the California Assembly Committee on Natural Resources Planning and Public Works held in September of 1964 to study "the necessity, desirability and feasibility of establishing a regional multipurpose district with broad powers under the law to develop and enforce a regional master plan." Hearings on Regional Planning, supra note 20.

326. This account of the Bi-State Agency legislation was drawn in part from $F$. Rose \& J. Rogers, Iake Tahoe: Preservation and Orderly Growth, June 6, 1969 (unpublished student paper loaned to the author by Professor I. Michael Heyman, Professor of Law, School of Law, University of California, Berkeley).

327. See Joint Study Comm. Report, supra note 8.

328. Id. at 5-6.

329. Id. at 29-42. 
15 members. The five county governments and the city of South Lake Tahoe were to appoint one member each. The two governors were to appoint one member each representing a state agency having an interest in the basin. ${ }^{330}$ Six members-at-large were to be designated. Each governor was to appoint three; one legal resident and registered voter in the region; one seasonally domiciled property owner, and one person who inight, but need not, have any of the other qualifications. A final advisory meinber was to be appointed by the President of the United States on concurrent request by the two governors.

Legislation substantially adopting the recommendations of the Joint Study Committee report was introduced in the 1967 California Legislature. ${ }^{331}$ The Legislature finally did adopt the proposal, but with modifications. ${ }^{332}$ Most notably, the inembership on the proposed commission was decreased froin 15 to 10 , dropping four of the inembers-at-large and the federal advisory member. ${ }^{333}$

Legislaton introduced in Nevada the following year made still further variations from the joint study proposal. ${ }^{334}$ First the bill required concurrent majorities of the inembership from each state for action. Second, the bill contained a caveat that its powers were restricted to matters "general and regional in application." Third, the bill deleted the agency's authority to approve public works projects of the states. Fourth, the bill shifted responsibility for the creation of a regional plan from the agency itself to a subordinate "advisory planning commission." Fifth, a new provision required that any business or recreation establishment required to be separately licensed by the state must be recognized as a permitted and conforming use. This provision was said to assure that the commission would not pose a threat to Nevada gambling at the lake. Finally, the bill included a budget limitation.

Since the agency agreement required identical bills from each legislature, the matter was now thrust back to the California Legislature which yielded to the Nevada version of the bi-state compact. ${ }^{335}$ Congress completed the compact by ratification in December of $1969,{ }^{336}$ and the agency came into being in 1970. Tlius, soine three years from the time of the original bill and ten years from the first informal meetings of local planning agencies, the basin got a formal

330. Id. at 30 .

331. A.B. 1362, Cal. Reg. Sess. (1967). It was introduced by Assemblyman Z'Berg, who conducted the 1965 hearings.

332. CAL. Gov't CODE $\S \S 66800-01,67000-130$ (West Supp. 1971).

333. Id. \& 67041.

334. S.B. 9, Nev. Reg. Sess. (1968).

335. CAL. Gov't COde $\$ 67040$ (West Supp. 1971).

336. Act of Dec. 18, 1969, Pub. L. No. 91-148, 83 Stat. 360. 
planning agency whose membership and powers represented a considerable modification of the Joint Study Committee Report.

Since the Bi-State Agency has only recently come into being, it would be imprudent to make any extensive assessment of this new planning effort. This basic point must be noted, however: the BiState Agency does not overcome the institutional obstacles that seem to have hampered planning activities here and elsewhere in the past. While it is true that the Agency does have enforcement powers that will enable it to carry out its plans with a directness that was never available before, at least two important obstacles to planning reinain. First, there is no reason to expect that this agency, any more than its predecessor, will be able to reconcile development restrictions with private land rights, a familiar dilemma of land planning agencies everywhere. Second, the agency that emerged will be, after all, dominated by local political interests. Without resorting to outright determinism, it is fair to say that these local interests remain vulnerable to the same kind of constraints that have affected local city and county governments in the basin up to now.

\section{A Perspective on Planning}

One consistent theme throughout the period of modern development at Tahoe has been the notion that the area needs basin-wide planning. Having examined the development of the 1980 Plan and the Bi-State Agency, as well as the sewage export program, it may be fruitful to give this impulse some scrutiny. What is evident is that this consistent theme contains several different kinds of ambiguity. ${ }^{337}$

Thus at one level, planning means the assembly and organization of objective data as a precondition to rational decision-making. But there has been no lack of this sort of planning. In fact, at that level, the Tahoe basin has had excellent planning. Despite the governmental or administrative fragmentation the sewer study and the 1980 Plan were able to perform this intelligence function with conspicuous success.

Obviously, the intelligence-gathering function alone is not conventionally regarded as the end of planning. Something more than mere fact-gatherimg is foreseen. This suggests a second possible definition: specifically, the notion that with correct data, right decisions must follow. ${ }^{338}$ Time has disabused us of that view of planning. ${ }^{339}$ Even

337. Students of local government will recognize that this perspective owes much to what Michelman and Sandalow have called the "revisionist" strain in local government literature. See F. Michelman \& T. Sandalow, Materials on Government in Urban AREAS 573-83 (1970).

338. The notion that local government is outside the realm of policy conflict is developed and criticized in URBan GovernMENT: A READER IN ADMTISTRATION AND 
assuming, arguendo, that one can discern right decisions from data, it is by no means certain that the right decisions will be self-evident. And they are even less likely to be self-executing. This does not mean that data and decisions are unrelated, of course: there seems to be good reason to believe that the success of the sewage export project is traceable at least in part to the comprehensive and forceful presentation of the hazards involved in not exporting. But much data are available on the penalties of excessive land development and up to now, these have not served to restrict land development. ${ }^{340}$

Again, the notion that Tahoe needs basin-wide planning may mean simply that proliferation of governments is in itself an evil: that there are too many people to keep track of, too many possibilities for diverse pohicy and too much difficulty of coordination. But it is not at all clear that proliferation of governments itself produces meaningful obstacles. The experience at Talioe suggests rather that basin-wide problems do get solved even without basin wide government when there is general agreement that they should be solved. There are a variety of examples of this: the existence of some 80 water districts has never prevented the dehvery of water. And the most conspicuous example of all is sewage: though behind schedule, though at enormous cost, the sewage problem in the Tahoe Basin is being solved, without a regional agency.

A number of possible reasons for this can be suggested. One is that a great deal of de facto regional government takes place even when there is local fragmentation. Thus the Lahontan Regional Water Quality Control Board and the Nevada Division of Health were engaged in regional policy-making on the water quality issue all the time the campaign to create the Bi-State Agency was under way. A second is that some regional administration can be carried out by way of negotiation or bargaining outside a unified administrative framework. Again the example is sewer-building. The ten districts have carried out the export program by some elaborate intramural bargaining. It is possible that the job would have been done more quickly and efficiently by a single large organization, although this is not so certain as one's first impulse might suggest. ${ }^{341}$

PoLrTics 209-98 (E. Banfield ed. 1961). For a subtle appreciation of the planncr's role in policy conflicts see id. at $488-97$.

339. E. BANFIELD \& J. Wilson, supra note 321, at 187-203.

340. A vivid suggestion of the scope of the problem is in Berliner, Plague on the Land, 5 CRY CALIFornia, No. 3, at 1-12 (1970).

341. Questions about the virtues of consolidation have been raised by Janes $R$. Schlesinger, who asserts that "large organizations suffer from a geometric increase in the difficulty of a) successfully communicating intentions and procedures, b) establishing a harmonious system of incentives, and c) achieving adequate cohesion anong nu- 
Finally, on possible inference from the notion of basin-wide planning is that local governments are not doing their job and ought to be replaced by the states or federal agencies. Some people clearly have seen the Tahoe problem as requiring extensive authoritative intervention by the state or federal governments. ${ }^{342}$ Not surprisingly, any demand for state or federal involvement has provoked intense opposition from within the basin. Local interests within the basin are characteristically ready to roll out all the armory of home rule and selfgovernment at any suggestion of outside interference-just as, unsurprisingly, they would be in Watts or Scarsdale. ${ }^{343}$ Thus up to now, outside interference has been at its best when it is most indirect-as through the Lahontan Regional Water Quahity Board-or its most palatable-as in the giving of inoney.

Viewed in this hight, it is necessary to ask whether the new Bi-state Agency has not incurred the worst of both worlds. Comparing the agency bill as passed with the original legislation makes it clear that the agency which emerged is, essentially, a local agency. Still, it excites the kind of rhetoric that one might fairly expect if it were a full-fledged imperial government.

\section{VIII}

\section{REPRISE: A FINAL WORD ON WHO DID AND DID NOT DO WHAT}

Never since the creation has a particle of that water turned a wheel, or fed a fountain for human thirst, or served any form of mortal use. Perhaps the eyes of not a hundred intelligent spirits on the earth have yet looked upon that scene. Has there been any waste of its wild and lonely beauty? Has Tahoe been wasted because so few appreciative souls have studied and enjoyed it? If not a human glance has yet fallen upon it, would its charms of color and surroundings be wasted charms? $?^{344}$

[I]t may well be that if and when Lake Tahoe turns green it will be the ouly green thing in the basin. ${ }^{345}$

merous individuals and sub-units with sharply conflicting wills." J. Schlesinger, quoted in W. HIRsCH, THE ECONOMICS OF StATE AND LoCAL GOVERNMENT 274 (1970).

342. See, e.g., Tahoe: Time for Tough Federal Action, 1 CRY CALIFORNA, No. 1, at 26-29 (1965-1966).

343. See, e.g., Tahoe Daily Tribune, July 3, 1970, at 3, cols. 1-3, criticizing the Bi-State Agency: 'The people of the Tahoe Basin did not 'get the agency created.' The people of the Tahoe Basin have never been asked if they would like an appointive government ruling here and we suggest that maybe it's about time they were asked, in an election."

344. Sermon by Rev. Thomas Starr King, quoted in G. HrNkLE, B. HINKLE, supra note 18, at 274. King was an eminent New York preacher. The Hinkles say the sermon "described the lake as a vital symbol of the omnipotence and purity of the creator." Id. at 273.

345. Letter by P.E. McGauhey protesting a shoreline construction permit, quoted 
On review, it seems striking how much and how often the central initiatives in the Tahoe water quahity situation have been taken by agencies with a state-wide constituency. There was strong evidence of this state involvement in the matter of sewage disposal control. Wiht regard to sedimentation, it may be even more evident. The same seems true of the separate but related effort for "planning" in the basin.

Correspondingly, it is noteworthy how little of this process has depended on anything that conventionally passes under the name of "enforcement" in a legal sense-how much has depended on unction and guile, or as one is almost tempted to say, bluff. It is tempting to be nihilistic about any impulse to rely on cooperation and persuasion in any effort to solve public problems. Yet in the case of Tahoe at least, it does appear that something like cooperation and persuasion has accomplished some things. On the other hand, it is difficult to conceive of any "enforcement" process that would have been materially more effective.

Outside the realm of administrative enforcement, and perhaps ahead of it, the most obvious contribution to the solution of Tahoe water quality problems has been money. Much of the money has been local money, as was inevitable, in view of the fact that it was buying local facilities and services for local use. However, an extraordinary amount has come from outside-from the Federal Water Quality Administration, the Economic Development Administration and the California state financing program.

It would be uncharitable and quite wrong to imply that none of the water quatity control effort has come from inside the basin. Obviously, large portions of the energy and enterprise for water quality control at Tahoe was generated by people who hive and work there permanently. On the other hand, it is striking how often the local polity has seemed to be following an outside initiative.

The question "who?" can be asked and answered in another way. This Article set out to analyze the "legal" problems of water quality control at Lake Tahoe. One necessary inference from the material at hand is that important portions of the solution have not been "legal" at all except in a very attenuated sense. Put more bluntly, it is notable how hittle lawyers have had to do with the solutions of Tahoe's problems. This is an intriguing if somewhat chastening point of career information. Lawyers have had roles in the Tahoe situation, of

in Lake Tahoe Newsletter, supra note 29, vol. 12, no. 2, at 4. McGauhey is chairman of the Lake Tahoe Area Council board of consultants, the body that supervised the Lake Tahoe Area Council water quality studies. 
course: they have drafted the bond indentures, written the ordinances, negotiated the inter-district agreenents, and so forth. Yet if one were to ask which profession has had most to do with accomplishing what has been accomplished at Tahoe, the answer probably would have to be the engineers.

And what have all these efforts accomplished? That depends, of course, at least in part on one's expectations. Surprisingly the technical data, though plentiful, do not coinpletely answer the question. Figures froin the Joint Water Quality Investigation suggest that the amount of nitrogen in the Lake has in fact increased since 1962, but remains well within the limits of the 1966 standards. $^{346}$ These figures also suggest that phosphorus, which has in the past been regarded as plentiful, actually decreased over the same period..$^{347}$ Moreover, it appears certain that there will be less effluent in the basin five years from now than there is now and it is possible that sedimentation also will be cut down. On the other hand, no one seems prepared to say exactly how much phosphorus and nitrogen is needed to provoke exactly what sort of algae growth.

The qualitative evidence of sedimentation and algae growth remam. And the quality of the lake remaims a topic of great interest around the lake itself and among potential vacationers. It is, of course, possible that there has been a real increase in the number of algae in the lake, though this cannot be documented absolutely. It is also possible that there have been more people around to see the algae that are there; or that the algae and the people have tended to concentrate in the same places; or that people have grown to dislike algae more.

On the other hand, it is extremely difficult to separate any possible disappointment about clarity from a more general disappointment about development at the lake in general. After all, clarity is not a goal in itself. Lake Vanda is clearer than Lake Tahoe, yet it is not a spa because it lies inland from McMurdo Sound in Antarctica. ${ }^{348}$ By

346. Testing in 1962 showed concentrations of eleven micrograms per liter of nitrate, nitrite and ammonia. See CoMPrEHENsive STUDY, supra note 19, at 90. The 1966 objectives set a inaximum of 25. Lake Tahoe Water Quahty Control Policy, supra note 201, at 11; Nevada Division of Health, Water Pollution Control Regulations, July 16, 1957, as amended, July 1, 1967, at 56. The latest governmental figures indicate that concentrations did not exceed 19.1. CALIForNIA-NEvADA-FEDERAI JOINT WATER QUALITY INVESTIGATION OF LAKE TAHOE, 1967-68, at iii.

347. The COMPrenensive Study, supra note 19, at 90, reported phosphate concentrations of seven micrograms per liter. The 1966 standards set a nraximum of ten. Lake Tahoe Water Quality Control Policy, supra note 201, at 11; Nevada Division of Health, Water Pollution Control Regulations, supra note 346, at 56. The 1967-68 survey reported that mean values did not exceed 3.5. CALIFORNIA-NEvadA-Federal JOINT WATER QUALITY INVESTIGATION OF LAKE TAHOE, 1967-68, at iii.

348. See Goldman, Aquatic Primary Production, 8 AMER. Zoologist 31, 37 (1968). 
contrast, California's Clear Lake retains considerable popularity as a vacation spot, though its clarity is at war with its name. ${ }^{340}$ Tahoe's problem, thus, is at once more and less than water quality. Keeping Tahoe clean is only one aspect of a larger design to preserve Tahoe as an ambience.

In this framework, it may be useful to recall something about Tahoe's past. It seems that part of the war over Lake Taloe must be understood in the context of Tahoe's role as the Saratoga of the Pacific. It seems possible to infer that at least some of the campaign for Lake Tahoe is actuated by sheer nostalgia for the gemutlicht associated with Tahoe, not in the 1840 's, but circa 1890 to $1950 .^{350}$

Some of this can be seen by considering what is perhaps the second most deplored fact about Tahoe-or was in the 1960's. That is the presence of big-time gambling at the lake. It does seem that gambling has imposed some costs on the Taloe basin. The presence of a garish high-rise on the lake's shore surely can qualify as a mote in the eye of the beholder-particularly if the only way to avoid being a beholder is to pay 25 or 50 dollars to occupy space in the garish highrise. And it is undoubted that gambling created the great slurb of gas stations and motels along the South Shore. Again, gambling may well bring people to the basin who might never have come there otherwise: a study sponsored by a gambling entrepreneur in the mid-1960's estimated that 80 percent of all the tourism in Nevada was induced by gambling. ${ }^{351}$ Once there, they are likely to put other strains on the environment: they may camp, water-ski and enjoy the pristine clarity of the Lake, just like the non-gamblers.

Yet it might be-might have been-possible to contain substantial ainounts of gainbling with rather limited incursions into the natural environment. A high-rise is, in many ways, a much more efficient use of scarce environmental resources than a subdivision. It takes up less ground for floor space and roadways. It takes only a single sewer line, water line and electric line. Many of Taloe's gambling customers come by bus, and whatever one may care to think about the exploitative character of commercial gainbling for people who travel by bus, it is, in itself, less of an environmental hazard than coming by car. It seems necessary to infer that at least part of the objection to gainbling comes about, not because of the costs it imposes on the en-

349. Id.

350. For further evidence of this view see R. M. Smith, Lake Tahoe Area Council, An Exchange of Correspondence Relative to Philosophies of Future Planning for the Lake Tahoe Area, May 1960.

351. This figure includes Reno and Las Vegas, which do not have Tahoe's natural allure. See Economic Research Assoc., The Role of Gaming in Nevada's Economy III-6 (1964) (prepared for Harrah's Club). 
vironment, but rather because of principled objections to gambling, per se.

Over the years, there have been schemes to make Tahoe a national park. $^{35 s}$ It is intriguing to speculate on what sort of alternative fate such a decision would have dictated for the basin. Surely the problein of retaining water clarity would have been easier. If one's point of coinparison is Crater Lake in Oregon, the result is surely attractive-a large, underpopulated woodland retreat. On the other hand, if one thinks of Yosemite, one recalls that park status alone does not avoid all the evils and difficulties attendant on overcrowding.

The result, of course, was a compromise. There is public land in the Tahoe basin, and there may be more. But there is also plenty of big-time gambling, and so far it seems to have been designed so as to make maximum impact on the environment. Meanwhile large sums of state and federal money have been put up-and will be put up-to permit the most extensive and disruptive kind of private construction. The lake is fairly clean, but at great cost. Undoubtedly some people are happy with the situation-perliaps a great many. But if one had been set in 1950 to the task of designing an optimal future for the Tahoe basin, it is hard to believe it would have come out quite this way.

352. For early Tahoe National Park Bills, see 33 CoNo. REc. pt. 1, at 762 (1900); 50 CoNG. REC. pt. 1, at 133 (1913); 56 CoNG. REC. pt. 6, at 5538 (1918). 